\title{
Transfer of human $\alpha$-synuclein from the olfactory bulb to interconnected brain regions in mice
}

\author{
Nolwen L. Rey • Geraldine H. Petit • Luc Bousset • \\ Ronald Melki $\cdot$ Patrik Brundin
}

Received: 5 February 2013 / Accepted: 26 July 2013 / Published online: 8 August 2013

(C) The Author(s) 2013. This article is published with open access at Springerlink.com

\begin{abstract}
Synuclein ( $\alpha$-syn) is a protein prevalent in neural tissue and known to undergo axonal transport. Intracellular $\alpha$-syn aggregates are a hallmark of Parkinson's disease (PD). Braak and collaborators have suggested that in people who are destined to eventually develop PD, $\alpha$-syn aggregate pathology progresses following a stereotypic pattern, starting in the olfactory bulb (OB) and the gut. $\alpha$-Synuclein aggregates are postulated to spread to interconnected brain regions over several years. Thus, propagation of the pathology via neural pathways can potentially explain how $\alpha$-syn aggregates spread in PD. We have now studied if $\alpha$-syn can transfer from the OB to other brain
\end{abstract}

Electronic supplementary material The online version of this article (doi:10.1007/s00401-013-1160-3) contains supplementary material, which is available to authorized users.

\section{N. L. Rey $(\varangle) \cdot$ G. H. Petit · P. Brundin}

Neuronal Survival Unit, BMC B11, Department of Experimental

Medical Science, Wallenberg Neuroscience Center,

Lund University, Sölvegatan 19, 22184 Lund, Sweden

e-mail: Nolwen.Rey@med.lu.se

G. H. Petit

e-mail: Geraldine.Petit@med.lu.se

P. Brundin

e-mail: Patrik.Brundin@med.lu.se; Patrik.Brundin@vai.org

L. Bousset $\cdot$ R. Melki

Laboratoire d'Enzymologie et de Biochimie Structurale, UPR 3082 CNRS, Bâtiment 34, Avenue de la Terrasse,

91190 Gif-sur-Yvette, France

e-mail: bousset@lebs.cnrs-gif.fr

R. Melki

e-mail: Ronald.Melki@lebs.cnrs-gif.fr

P. Brundin

Center for Neurodegenerative Science, Van Andel Institute,

333 Bostwick Avenue N.E., Grand Rapids, MI 49503, USA structures through neural connections, by injecting different molecular species of human $\alpha$-syn (monomers, oligomers, fibrils) into the $\mathrm{OB}$ of wild-type mice. We found that non-fibrillar human $\alpha$-syn is taken up very quickly by $\mathrm{OB}$ neurons. Within minutes to hours, it is also found in neurons in structures connected to the OB. Conversely, when we injected bovine serum albumin used as a control protein, we found that it does not diffuse beyond the $\mathrm{OB}$, is rarely taken up by OB cells, and does not transfer to other structures. Taken together, our results show that $\mathrm{OB}$ cells readily take up $\alpha$-syn, and that monomeric and oligomeric, but not fibrillar, forms of $\alpha$-syn are rapidly transferred to interconnected structures within the timeframe we explored. Our results support the idea that $\alpha$-syn can transfer along neural pathways and thereby contribute to the progression of the $\alpha$-syn-related pathology.

Keywords $\alpha$-Synuclein - Olfactory pathway - Olfactory bulb $\cdot$ Transfer $\cdot$ Microglia $\cdot$ Parkinson's disease

\section{Introduction}

Parkinson's disease (PD) is characterized by abnormal cytoplasmic inclusions, mainly composed of misfolded $\alpha$-synuclein ( $\alpha$-syn) [27, 58] in neuronal soma (Lewy bodies) and neurites (Lewy neurites). $\alpha$-Syn is a soluble protein, structured in $\alpha$-helices when associated to membranes. Under pathological conditions it oligomerizes and aggregates into fibrils arranged in $\beta$-rich sheet structures $[16,17,57]$. Despite the current lack of evidence that aggregated/misfolded $\alpha$-syn is infectious between individuals [35], it has been proposed that aggregated/misfolded $\alpha$-syn can behave in a prion-like fashion within the nervous system of one individual. This means that aggregated/ 
misfolded $\alpha$-syn can induce the native endogenous $\alpha$-syn to adopt an abnormal conformation within the same cell. The misfolded $\alpha$-syn is then released into the extracellular space and is taken up by a neighboring cell. Once inside the new cell, the misfolded $\alpha$-syn can seed further $\alpha$-syn misfolding and aggregation. Thereby the protein acts as a template for misfolding that transmits the disease process from one cell to another. This intercellular transfer of misfolded $\alpha$-syn is hypothesized to contribute to the progressive spread of Lewy pathology in the nervous system in PD and other synucleinopathies [1, 11, 22, 30]. Earlier post-mortem studies of Lewy pathology in PD brains had led to the proposal that it gradually spreads throughout the nervous system following a predictable anatomical pattern [6, 8]. Braak and co-workers [5] suggested that Lewy pathology first develops in the olfactory bulb (OB), the anterior olfactory nucleus (AON), and in the dorsal motor nucleus of the vagus nerve, and based on neural connections to regions affected in later disease stages, they proposed that the pathology spread along protracted unmyelinated axons to interconnected regions. We, and others, have suggested that this spreading results specifically from axonal transport of $\alpha$-syn, followed by a cell-to-cell transfer of misfolded $\alpha$-syn to neighboring neurons. Numerous in vitro and in vivo studies show that $\alpha$-syn can transfer between cells and seed aggregation in the recipient cell $[2,18,19,25,29,45,50,62]$. Notably, the slow and fast intra-axonal transport of $\alpha$-syn has also been well described in vitro $[36,56,59]$, and studies using neurons in microfluidic chambers demonstrate that fibrillar and oligomeric $\alpha$-syn can be taken up from the medium and transported intra-axonally in both anterograde [25] and retrograde [61] directions. Finally, recent studies demonstrated that $\alpha$-syn aggregates appear in widespread brain areas, 1-6 months after injection of preformed $\alpha$-syn fibrils into the striatum or cortex of mice [43, 44]. This suggests axonal transport of an aggregation-prone $\alpha$-syn, although it is not absolutely clear if the $\alpha$-syn aggregates can transfer from one neuron to another and develop in regions that are not directly connected to the injection sites. Moreover, the ability of $\alpha$-syn to spread from anatomical regions suggested to be affected early in PD to brain areas that are impacted later on has so far not been explored. With the background that Lewy pathology in olfactory structures and impairments in olfaction both appear early in PD [20, 21], we targeted the OB. For the first time, we stereotactically injected different molecular species (monomers, oligomers composed of soluble high molecular weight species, and fibrils) of recombinant human $\alpha$-syn into the OB of normal mice. We then characterized in detail the transfer of $\alpha$-syn to interconnected brain regions over $72 \mathrm{~h}$. Our findings indicate that $\alpha$-syn monomers and oligomers are most rapidly and readily transferred from the injection site to interconnected brain regions. We observed a particular pattern of spread that matches known neural connections in the brain, but we cannot conclude with certainty that this transfer occurred by classical axonal transport. Our results supports the notion that transport of $\alpha$-syn oligomers between interconnected regions might be important in the spreading of $\alpha$-syn pathology between brain regions in PD.

\section{Materials and methods}

Animals

We purchased C57B1/6J 3-month-old female mice from Charles River Laboratories and housed them six per cage under a 12-h light/12-h dark cycle with access to food and water ad libitum. The housing of the animals and all procedures were in accordance with the international guidelines and were approved by the Malmö-Lund Ethical Committee for Animal Research.

Synthesis of different molecular species of recombinant wild type human $\alpha$-syn

We expressed recombinant S-tagged wild-type (WT) human $\alpha$-syn in Escherichia coli strain BL21 (DE3) (Stratagene) and purified it as described previously [26]. We determined $\alpha$-syn concentration by spectrophotometry using an extinction coefficient of $5,960 / \mathrm{M} / \mathrm{cm}$ at $280 \mathrm{~nm}$. Pure $\alpha$-syn $(0.5 \mathrm{mM})$ in $50 \mathrm{mM}$ Tris- $\mathrm{HCl}, \mathrm{pH} 7.5,150 \mathrm{mM}$ $\mathrm{KCl}$ was filtered through sterile $0.22 \mu \mathrm{m}$ filters and stored at $-80^{\circ} \mathrm{C}$.

We obtained $\alpha$-syn oligomers by incubating soluble S-tagged WT $\alpha$-syn in $50 \mathrm{mM}$ Tris- $\mathrm{HCl}(\mathrm{pH} 7.5,150 \mathrm{mM}$ $\mathrm{KCl})$ at $4{ }^{\circ} \mathrm{C}$ for 7 days without shaking. We separated oligomeric $\alpha$-syn from monomeric $\alpha$-syn by size exclusion chromatography (Superose 6 HR10/30, GE Healthcare). To achieve fibril assembly, we incubated soluble S-tagged WT $\alpha$-syn under continuous shaking in an Eppendorf Thermomixer set at 600 rotations/min and $37^{\circ} \mathrm{C}$. We assessed the nature of the oligomeric and fibrillar species using a Jeol 1400 transmission electron microscope (Jeol Ltd.) following adsorption of the samples onto carbon-coated 200mesh grids and negative staining with $1 \%$ uranyl acetate. The images were recorded with a Gatan Orius CCD camera (Gatan).

\section{Fluorescent labeling}

Monomeric and oligomeric S-tagged $\alpha$-syn assemblies in $50 \mathrm{mM}$ Tris- $\mathrm{HCl}(\mathrm{pH} 7.5,150 \mathrm{mM} \mathrm{KCl})$ were buffer exchanged using NAP10 desalting columns (GE Healthcare) to phosphate buffered saline (PBS) buffer. We 


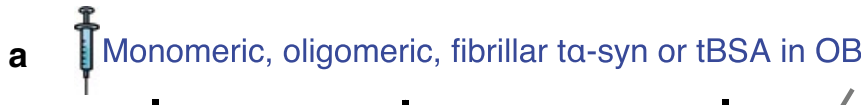
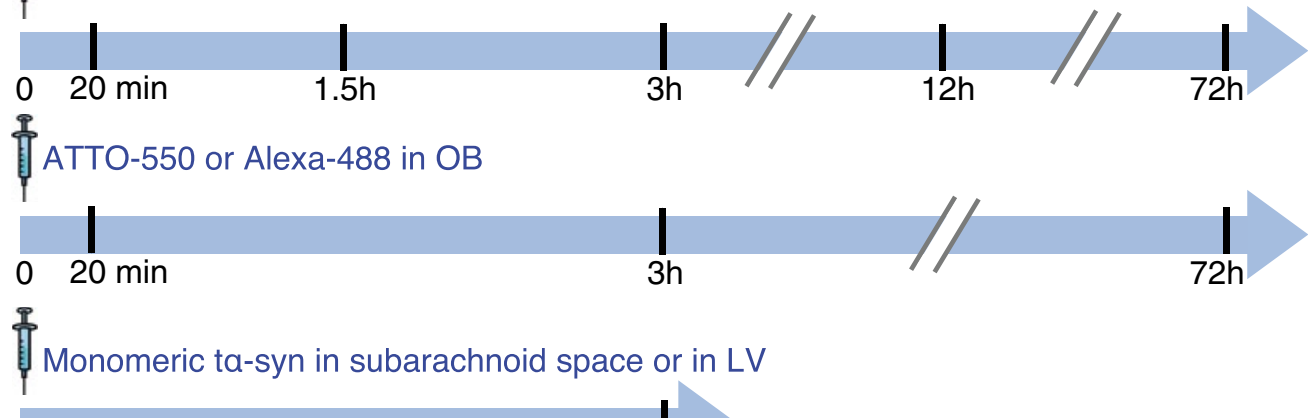

0
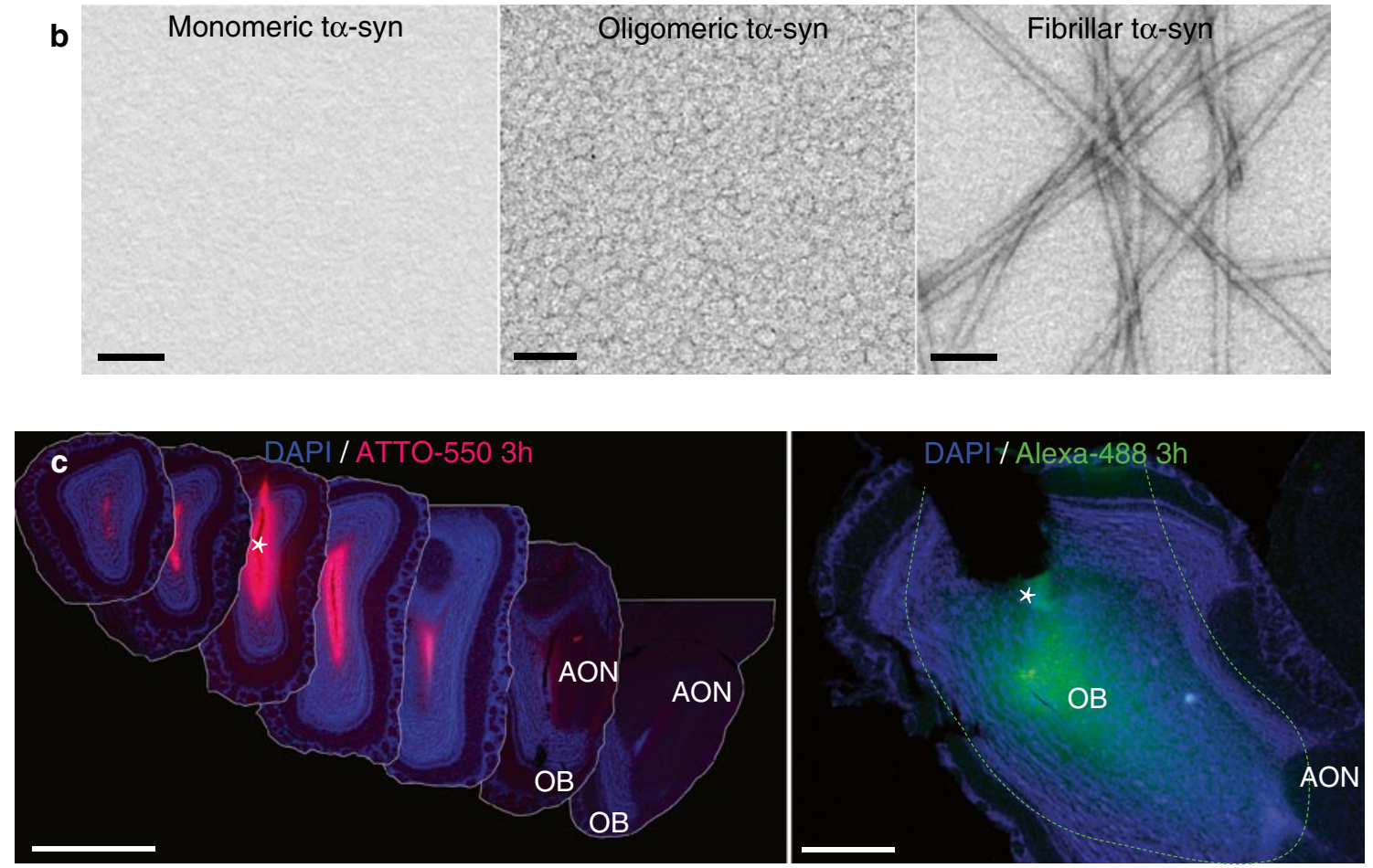

Fig. 1 Experimental design and controls of diffusion. a Experimental design. In wild-type mice, we stereotactically injected $\alpha$-synuclein $(\alpha$-syn) into the olfactory bulb (OB), the lateral ventricle $(\mathrm{LV})$ or at the level of subarachnoid space dorsal to the OB. Different molecular species of human recombinant $\alpha$-syn tagged with ATTO-550 and $S$-tag (t $\alpha$-syn) were injected: monomeric, oligomeric, or fibrillar $t \alpha-$ syn; or bovine serum albumin tagged with ATTO-550 (tBSA); or unbound ATTO-550 or Alexa-488 alone as control. We killed mice $20 \mathrm{~min}, 1.5,3,12$ or $72 \mathrm{~h}$ after injection for histology. b Characterization of recombinant $t \alpha$-syn. Negatively stained transmission electron micrographs of monomeric, oligomeric and fibrillar $t \alpha$-syn. Oligomer samples are homogeneous, and do not contain any $\alpha$-syn fibrils. Scale bar represent $100 \mathrm{~nm}$. c Photographs of the injected region in the OB $3 \mathrm{~h}$ after injection of unbound ATTO-550 or Alexa-488 (dissolved in

performed $\alpha$-syn labeling with ATTO-550 NHS fluorophore following the manufacturer instruction (ATTOTec Gmbh) using a protein:dye ratio of 1:2. We removed
PBS) into the OB of mice. The images illustrate how far the injected solution diffused in the neural tissue. Left panel is a montage of coronal sections of a brain injected with unbound ATTO-550 (inter-section interval $=450 \mu \mathrm{m}$ ). Three hours after injection, ATTO-550 diffused from the injection site to lateral layers of the $\mathrm{OB}$, and until the very anterior part of the AON, but not further. Scale bar $1 \mathrm{~mm}$. Right panel is a low magnification picture of a sagittal section of a brain injected with Alexa-488. At $3 \mathrm{~h}$ after injection, Alexa-488 diffused from the injection site to the posterior part of the $\mathrm{OB}$, the accessory olfactory bulb (AOB) and until the very anterior part of the anterior olfactory nucleus (AON), but not further. Dashed line represent the limit of Alexa-488 diffusion. Scale bar represent $500 \mu \mathrm{m}$. The white asterisk marks the injection site

unreacted fluorophore using NAP10 desalting columns. We centrifuged $\alpha$-syn fibrils at $16,000 \mathrm{~g}$ for $10 \mathrm{~min}(\mathrm{~min})$ and resuspended them twice in PBS and labeled them as 

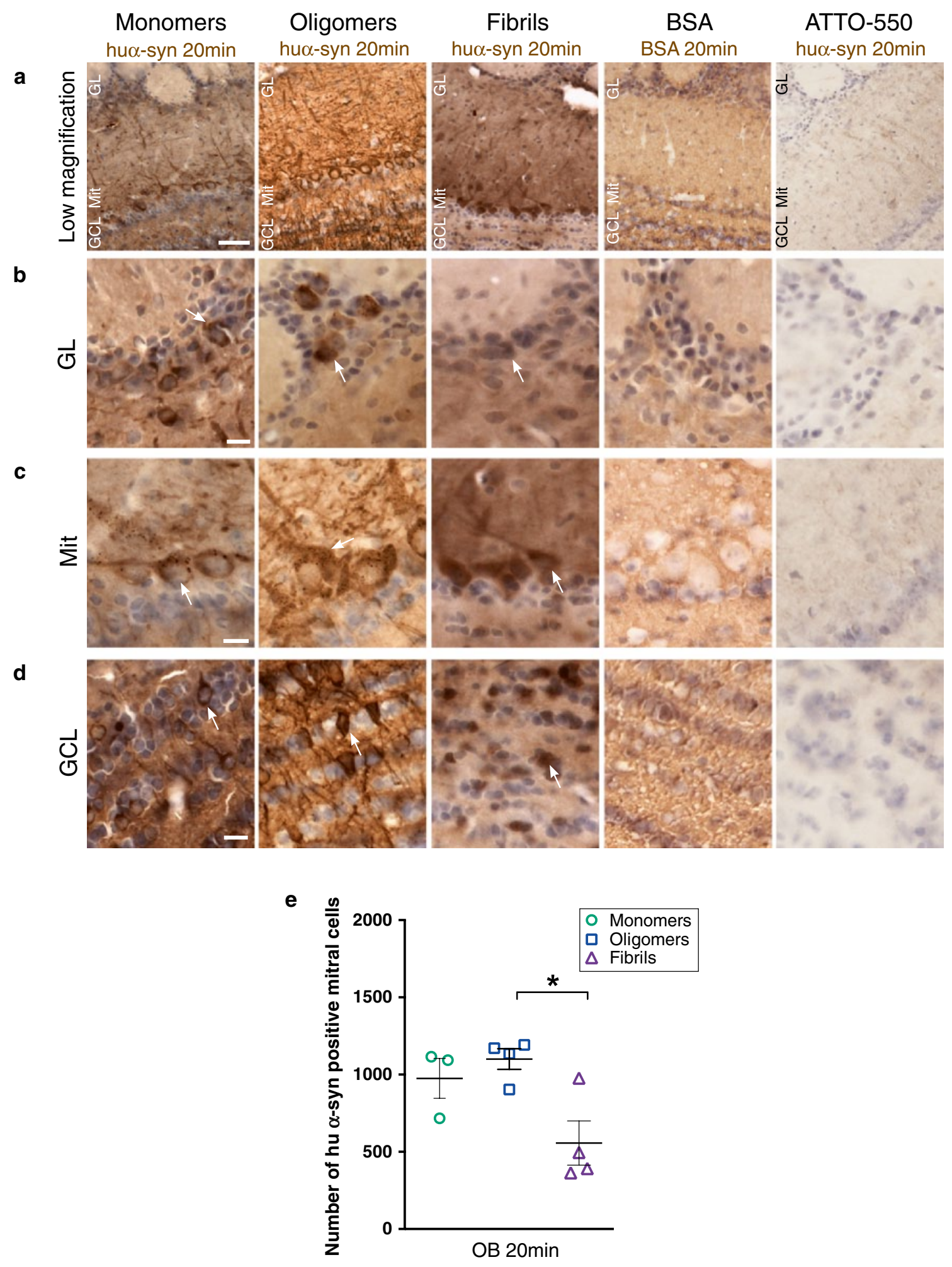

described above. We removed unreacted fluorophore by centrifugation at $16,000 \mathrm{~g}$ for $10 \mathrm{~min}$ and then resuspended the pelleted fibrils twice in PBS. In the rest of the article, we have denoted recombinant $\alpha$-syn tagged with ATTO550 and S-tag "t $\alpha$-syn". Lyophilized BSA was purchased form Sigma (ref A9418), dissolved in PBS at $5 \mathrm{mg} / \mathrm{mL}$ and labeled with ATTO-550 dye using a protein:dye ratio of 1:2 following the same procedure as described for soluble t $\alpha$-syn. Similarly, we have abbreviated BSA tagged with ATTO-550 as "tBSA". 
4 Fig. 2 T $\alpha$-syn is taken up by OB cells less than 20 min after injection in the OB. Hua-syn- (stained with syn211 antibody) and BSAstaining in the OB, $20 \mathrm{~min}$ after injection of t $\alpha$-syn, tBSA or ATTO550 into the OB: a low magnification pictures of the ipsilateral $\mathrm{OB}$ (GL/Mit/GCL) (scale bar $50 \mu \mathrm{m}$ ), or high magnification pictures (scale bar $10 \mu \mathrm{m}$ ) of glomerular layer (GL) (b), mitral layer (Mit) (c), and granular cell layer (GCL) (d) of the ipsilateral OB. At $20 \mathrm{~min}$ after injection of monomeric, oligomeric and fibrillar $t \alpha$-syn into the $\mathrm{OB}$, we detected hu $\alpha$-syn-positive cells in various layers of the $\mathrm{OB}$ (GL, Mit, and GCL), but no BSA-positive cells in the OB injected with tBSA. A diffuse BSA-staining was observed in extracellular space. To control for specificity of our immunohistochemistry protocol, sections from groups that were injected with ATTO-550 into the OB were stained for hu $\alpha$-syn, and did not reveal any hu $\alpha$-syn-positive staining. A white arrow points examples of huo-syn-positive cells. e Uptake of injected $\alpha$-syn at 20 min: number of hu $\alpha$-syn positive mitral cells in the ipsilateral $\mathrm{OB}$ at $20 \mathrm{~min}(H=6.053, P<0.04$, post hoc test: monomers/fibrils $P<0.05)$. Scatter plots show data from individual mice

As control solutions, we will use unbound ATTO-550 and Alexa-488 (unbound to proteins). To obtain them, the NHS groups of ATTO-550 and Alexa-488 NHS (5 mM) were reacted with Tris- $\mathrm{HCl}(\mathrm{pH} 7.5,200 \mathrm{mM})$ as a primary amine source at room temperature for $3 \mathrm{~h}$. The solution was then diluted to $200 \mu \mathrm{M}$ in PBS and stored them at $-80{ }^{\circ} \mathrm{C}$.

\section{Stereotactic injections}

We anesthetized 105 mice (3-month-old) with isoflurane/ oxygen/nitrogen mixture, and stereotactically injected $t \alpha-$ syn or tBSA into the OB, or other intracranial sites (control injections) as specified below. We performed the stereotactic injections using a glass capillary attached to a $10 \mu \mathrm{l}$ Hamilton microsyringe, and injected $0.8 \mu 1$ of protein or fluorophore solutions unilaterally in the $\mathrm{OB}$ (coordinates: AP: $+5.4 \mathrm{~mm}, L:-0.75 \mathrm{~mm}, \mathrm{DV}:-1 \mathrm{~mm}$ relative to bregma and dural surface).

The solutions we injected contained monomeric, oligomeric, fibrillar $t \alpha$-syn, monomeric untagged $\alpha$-syn or tBSA at a concentration of $1 \mathrm{mg} / \mathrm{mL}$ in sterile PBS. We perfused the mice $20 \mathrm{~min}, 1.5,3,12$ or $72 \mathrm{~h}$ after injection and collected brains (4 mice per group; Fig. 1a; supplementary Table 1). To examine how far injected vehicle (containing no protein) can diffuse, we also injected mice with unbound ATTO-550 (9 mice) or unbound Alexa-488 in PBS $(1 \mathrm{mg} / \mathrm{mL}, 6$ mice) into the OB and perfused them at one of three time points ( $20 \mathrm{~min}, 3,72 \mathrm{~h}$ ).

To control for the possible spread of $t \alpha-$ syn within the brain via cerebrospinal fluid, we performed control injections of monomeric t $\alpha$-syn in the subarachnoid space (on the top of the OB after breaking the dura mater; AP: $+5.4 \mathrm{~mm}, L:-0.75 \mathrm{~mm}$, DV: $0 \mathrm{~mm}$ relative to bregma and dural surface) or into the lateral ventricle (LV, AP: $+0.74 \mathrm{~mm}, L:-0.6 \mathrm{~mm}, \mathrm{DV}:-2.2 \mathrm{~mm}$ ). We injected three animals per location and perfused these mice $3 \mathrm{~h}$ after injection. Following initial pilot experiments, we chose the volume of solution we injected so that it resulted in sufficient amounts of protein in the OB to allow the study of transport, but without giving rise to significant diffusion to other brain structures. Due to retrograde leakage of the injected protein along the injection capillary tract, we had to exclude one mouse in each of the following groups: monomeric t $\alpha$-syn $1.5 \mathrm{~h}$, oligomeric t $\alpha$-syn $1.5 \mathrm{~h}$, monomeric t $\alpha$-syn $3 \mathrm{~h}$ and oligomeric t $\alpha$-syn $3 \mathrm{~h}$.

Immunohistochemistry and analysis

\section{Preparation of the tissue}

At 20 min, 1.5, 3, 12 or $72 \mathrm{~h}$ after injection, we anesthetized mice with sodium pentobarbital and perfused them transcardially with $0.9 \%$ saline followed by $4 \%$ PFA in phosphate buffer. We dissected the brains, post-fixed them for $2 \mathrm{~h}$ in $4 \%$ PFA and placed them in $30 \%$ sucrose in phosphate buffer. We stored the brains at $4{ }^{\circ} \mathrm{C}$ until sectioning. We cut the entire brains into $30 \mu \mathrm{m}$ free-floating coronal sections on a freezing microtome, and stored them in antifreeze solution at $4{ }^{\circ} \mathrm{C}$ until immunostaining. To control how far a protein-free solution could diffuse, we cut some brains injected with unbound Alexa-488 into $30 \mu \mathrm{m}$ freefloating sagittal sections, and brains injected with unbound ATTO-550 into $30 \mu \mathrm{m}$ free-floating coronal sections.

\section{Diaminobenzidine (DAB) stainings}

We stained coronal free-floating sections using primary antibodies anti-human $\alpha$-syn syn211 (monoclonal raised in mouse, 1:500, Invitrogen) or anti-BSA (raised in rabbit, $1 / 1,000$, Invitrogen) or anti-S-tag (1/1,000, Delta Biolab), and secondary antibodies biotinylated (Horse anti-mouse, 1/200, Vector lab; Donkey anti-rabbit 1/200, Abcam; Goat anti-rabbit, 1/200, Vector lab). For the detection of the antibody with $\mathrm{DAB}$, we used a standard peroxidase-based method (Vectastain ABC kit, and DAB kit, Vector Laboratories) with nickel enhancement. S-tag staining was carried out on one mouse per group at $1.5 \mathrm{~h}$ to confirm our observations from syn211 staining. Sections were then counterstained by haematoxylin. We analyzed these sections by conventional light microscopy (Eclipse 80i microscope; Nikon).

\section{Immunofluorescence staining}

We stained coronal free-floating sections with primary antibodies anti-human $\alpha$-syn syn211 (monoclonal raised in mouse, 1:500, Invitrogen), anti-Tuj1 (polyclonal raised in rabbit, 1/2,000, Covance), anti-Tuj1 (and monoclonal raised in mouse, 1/5,000, Covance), anti-BSA (raised 
Fig. 3 T $\alpha$-syn is localized within the somata of mitral cells in the OB 20 min after injection. We stained brain sections by immunofluorescence for Tuj1 (green), a neuronal marker, and for hu $\alpha$-syn or BSA. T $\alpha$ syn was identified both by its ATTO-550 fluorescent tag ( $r e d$ ) and by the hu $\alpha$-syn (syn 211 antibody) staining (blue). Similarly, in groups injected with BSA, the BSA was detected both by its ATTO-550 tag (red) and by BSA staining (blue). Confocal three-dimensional reconstructions (large panels) show ATTO-550 signal (red) colocalized with hu $\alpha$-syn staining (blue) within mitral cells (tuj1, green) in the OB of mice injected with monomers (a), oligomers (b) and fibrils (c), indicating that these cells contain hu $\alpha$-syn. We also occasionally detected BSA-positive punctae within Tuj1-positive mitral cells in mice injected with BSA (d). Smaller panels are confocal plans showing tuj1 (green), ATTO-550 (red), hu $\alpha$-syn or BSA (blue) staining, and merged pictures of green and red channels. Scale bars represent $10 \mu \mathrm{m}$ in every panel. White arrowheads point to t $\alpha$ syn punctae a
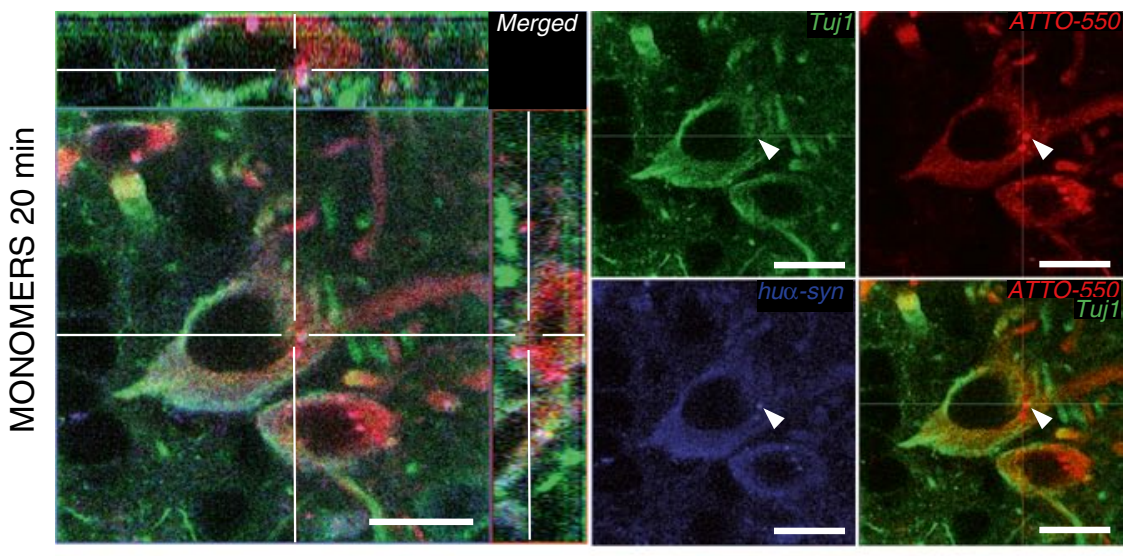

b
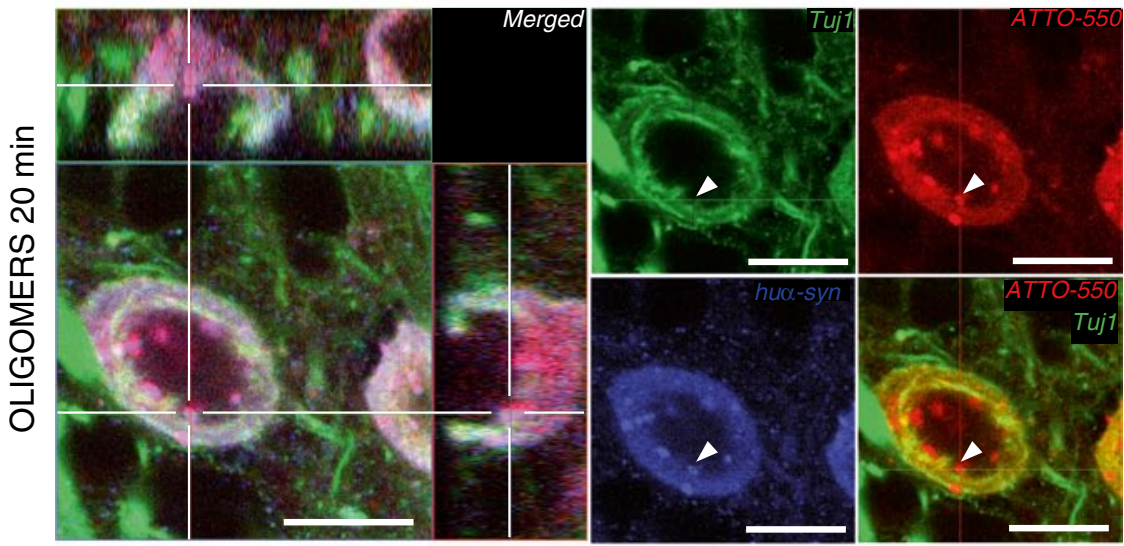

C
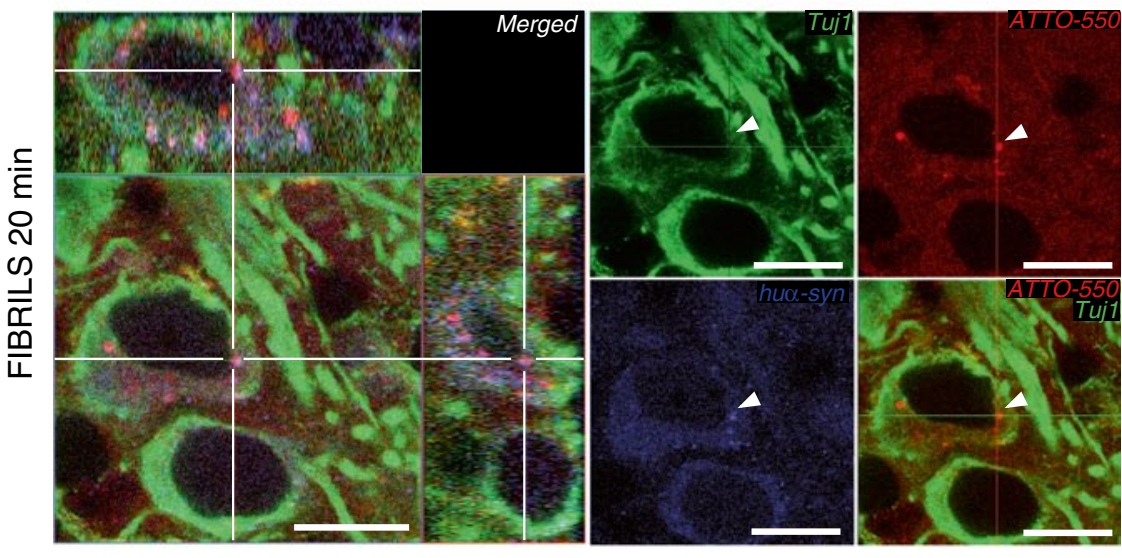

d
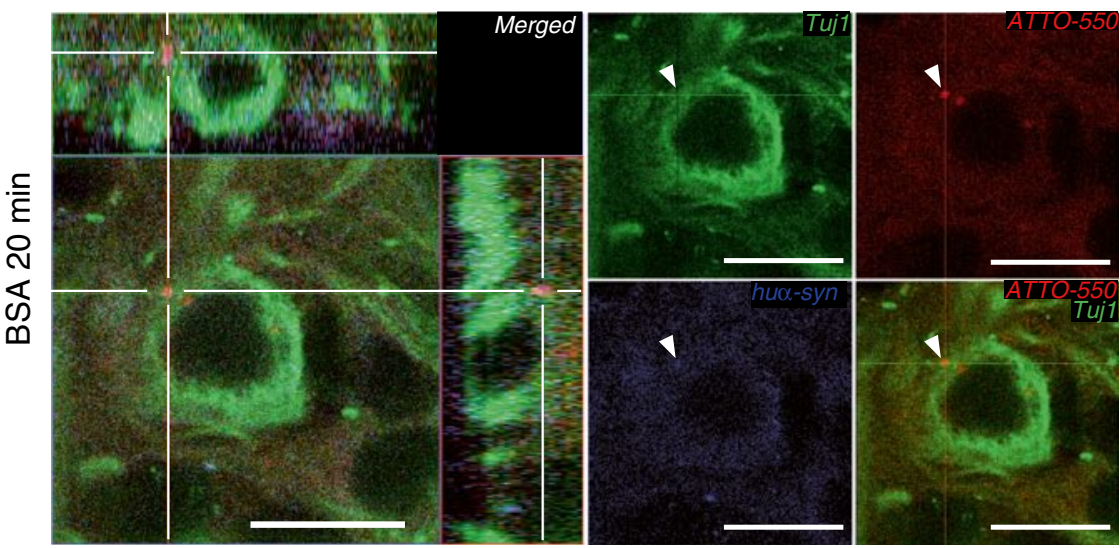
in rabbit, 1/1,000, Invitrogen), anti-Iba1 (raised in rabbit, 1:500, Wako/Nordic labs) and with the appropriate secondary antibodies Alexa-488 anti-rabbit, Alexa-488 anti-mouse, Alexa-647 anti-mouse, Alexa-647 anti-rabbit (raised in goat, 1:400, Invitrogen). We analyzed these specimens with a confocal laser microscope Zeiss LSM 510, equipped with $\mathrm{Ar}$ and $\mathrm{HeNe}$ lasers.

\section{Cell quantifications}

We quantified the number of hu- $\alpha$-syn positive cells in structures positive for hu- $\alpha$-syn (diaminobenzidine staining) using a computer-assisted mapping and cell quantification program (Stereo Investigator, MBF Bioscience, Williston, USA) coupled to a Zeiss Imager M2 microscope (Carl Zeiss Microimaging, Göttingen, Germany). We analyzed all the positive structures in four animals per group, at $40 \times$ magnification at $1.5 \mathrm{~h}$ time point; the OB and the piriform cortex of four animals per group at $20 \mathrm{~min}$ time point and at every time point from $20 \mathrm{~min}$ to $3 \mathrm{~h}$, respectively. In the $\mathrm{OB}$, only mitral cells were analyzed. Every positive cell (exhibiting staining in the whole cell body, or punctate within the cell body) was counted in each structure on a determined number of sections per structure, spaced by $240 \mu \mathrm{m}$, and distributed along the rostrocaudal axis at equivalent locations in each animal. Then we calculated the total number of cells detected per structure. Kruskal-Wallis tests and post hoc Dunn's multiple comparison analysis of the counting in the OB were performed on $n=4$ per group, using Prism 6.0, Graphpad.

\section{Results}

Control of the composition and the stability of t $\alpha$-syn preparations and experimental controls for stereotactic injections

Prior to injection, the monomeric, oligomeric and fibrillar states of recombinant $\alpha$-syn were confirmed by transmission electron microscopy (Fig. 1a). To define the size of our oligomers, we performed size exclusion chromatography. We found that they are composed of soluble high molecular species, eluted at $2 \mathrm{MDa}$ by this method (supplementary Fig. 1). It is worth noting that size exclusion chromatography does not allow an accurate measurement of the size of the protein since the mobility of the protein in the column depends also on its conformation and its charge [24]. Therefore, we cannot claim to know the precise size of our oligomers.

We also confirmed the stability of our different $\alpha$-syn assemblies over $72 \mathrm{~h}$ period (supplementary Fig. 2). After a $72 \mathrm{~h}$ incubation at $37^{\circ} \mathrm{C}$, we found that the monomeric $\alpha$-syn remains monomeric and soluble as shown by size exclusion chromatography (supplementary Fig. 2a, c) and sedimentation assay (supplementary Fig. 2e); oligomeric $\alpha$-syn does not polymerize or disassemble (size exclusion chromatography, supplementary Fig. 2b, d), and fibrillar $\alpha$ syn fibrils incubated in serum remain fibrillar (supplementary Fig. 2f).

We then controlled that our injections successfully targeted the rostrodorsal OB (supplementary Fig. 3a, b). To establish that any spreading of $\alpha$-syn from the OB to other brain regions that we might observe was not due to nonspecific diffusion or leakage from the injection site, we performed a series of important control experiments. Thus, to check that $0.8 \mu \mathrm{l}$ of solution that we injected into the OB does not diffuse to other structures, we injected unbound ATTO-550 or Alexa-488 in PBS at the same coordinates used for $t \alpha$-syn injection. We euthanized mice at different time points after injection ( $20 \mathrm{~min}, 3$, and $72 \mathrm{~h}$ ), dissected and cut brains sagittally or coronally to be able to monitor how far the injected solution diffused. We observed the maximum diffusion area at $3 \mathrm{~h}$ (Fig. 1c). At this time point, we observed (in sagittal and coronal sections) that the injected solution had diffused from the injection site in the $\mathrm{OB}$ to the anterior part of the AON. After $72 \mathrm{~h}$, we only detected the control fluorophore in the central part of the OB (supplementary Fig. 3c).

Neurons take up recombinant monomeric, oligomeric and fibrillar $\alpha$-syn in less than 20 min after injection into the olfactory bulb

We sacrificed mice injected with t $\alpha$-syn (monomers, oligomers or fibrils); tBSA or unbound ATTO-550 (as controls in the OB) $20 \mathrm{~min}$ after injection. Brain sections were stained with anti-human $\alpha$-syn (hu $\alpha$-syn) antibody (syn211) or with anti-BSA antibody. In mice injected with monomeric, oligomeric and fibrillar t $\alpha$-syn, we identified hu $\alpha$-syn-positive cells in different layers of the OB (Fig. 2a), i.e. the glomerular layer (GL, Fig. 2b), mitral cell layer (Mit, Fig. 2c), and in granule cell layer (GCL, Fig. 2d). The mitral cell layer contains the relay cells of the OB that project to central olfactory structures [49]. In contrast, no obvious BSA-positive signal in DAB was detected in OB cells (Fig. 2a-d). Instead, a diffuse signal in the extracellular space was seen. We also used the syn211 antibody to stain sections from brains injected with unbound ATTO-550. As expected, mice injected with only unbound ATTO-550 did not stain with the syn211 antibody and thus were negative for huo-syn (Fig. 2a-d; supplementary Table 2). Quantification, in DAB stained sections, revealed similar numbers of hu $\alpha$-syn positive mitral/tufted cells in the $\mathrm{OB}$ in groups injected with oligomers and monomers. The number of hu $\alpha$-syn positive mitral/tufted cells was, 


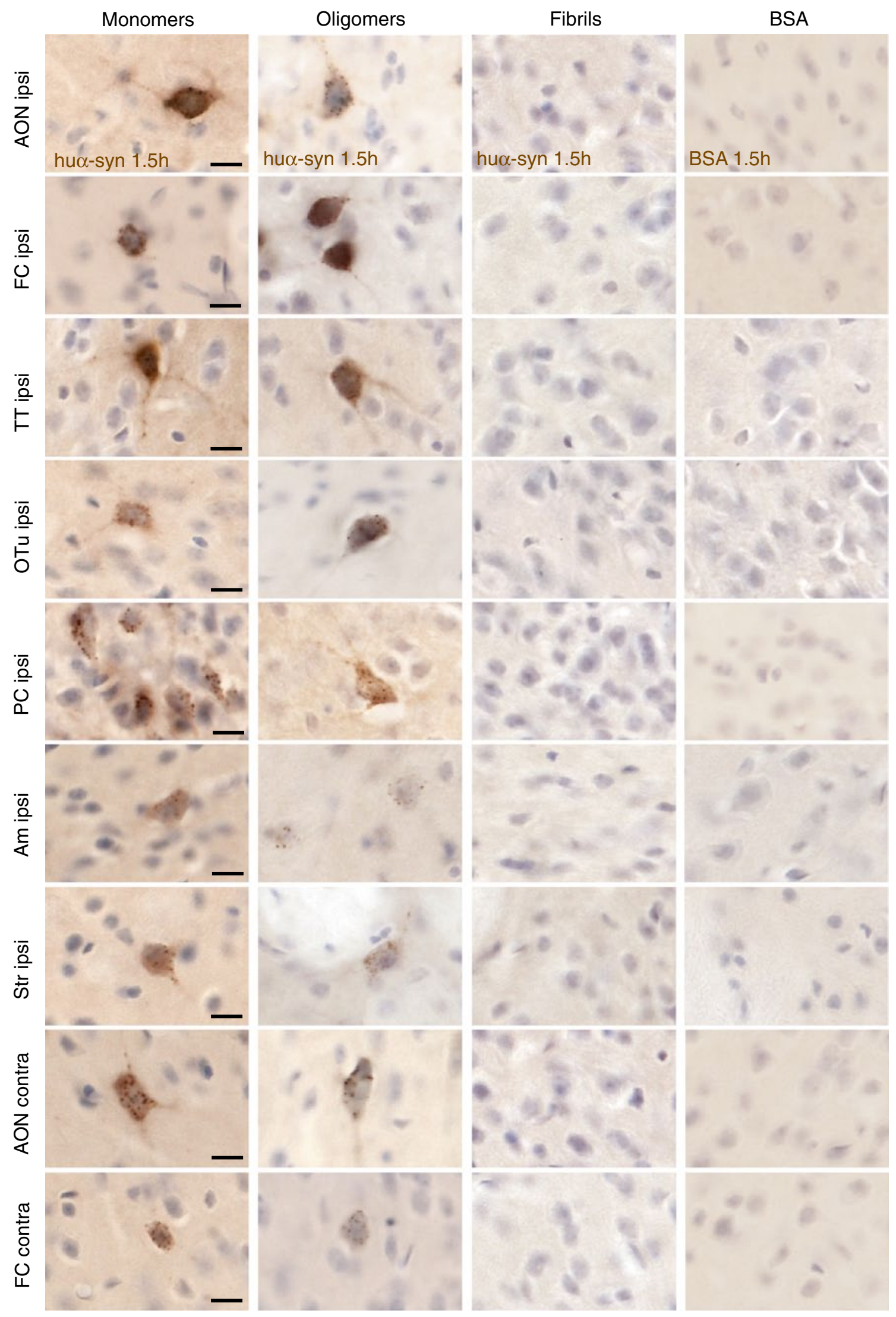


4 Fig. 4 Transfer of t $\alpha$-syn to other structures $1.5 \mathrm{~h}$ after injection into the OB. Images illustrating hu $\alpha$-syn or BSA staining at high magnification (scale bar $10 \mu \mathrm{m}$ ) in various brain areas. We detected hu $\alpha$-syn-positive cells in various brain structures $1.5 \mathrm{~h}$ after the injection of monomeric and oligomeric t $\alpha$-syn into the OB. We observed hu $\alpha$-syn-positive cells in the ipsi- and contralateral anterior olfactory nucleus (ipsi/contra AON), in ipsi- and contralateral frontal cortex (ipsi/contra FC), in ipsilateral tenia tecta (ipsi TT), olfactory tubercle (ipsi Otu), piriform cortex (ipsi PC), amygdala (ipsi Am) and striatum (ipsi Str). On the contrary, we detected hu $\alpha$-syn-positive cells only in the ipsilateral OB when we injected fibrillar t $\alpha$-syn. tBSA injected as a control protein into the $\mathrm{OB}$, was not detected in the brain, except in the injected $\mathrm{OB}$ where we observed only a diffuse staining in extracellular space, but no obvious BSA-positive cell

however, significantly lower in the group injected with fibrils (Fig. 2e).

We detected $\mathrm{t} \alpha$-syn both by its ATTO-550 fluorescent tag (in red), and by hu $\alpha$-syn (syn211) immunostaining (in blue) using confocal microscopy (Fig. 3a-c). Similarly, we detected injected tBSA by visualizing its' ATTO-550 fluorescent tag (in red), and by BSA immunostaining (in blue) (Fig. 3d). We detected neuronal cells by staining with a Tuj1 antibody (in green). In the mice injected with huo-syn monomers, oligomers or fibrils, we found that some Tuj1immunoreactive mitral/tufted cells (Fig. 3a-c), granule cells, and periglomerular cells (data not shown), exhibited both ATTO-550 fluorescence and syn211-immunoreactivity confirming that they had taken up huo-syn. In mice in which we had injected monomers or oligomers into the OB, the syn211/ATTO-550 signal appeared both as a diffuse staining and as punctae within the cell bodies and processes of Tuj1-positive cells (Fig. 3a, b). In mice injected with fibrillar t $\alpha$-syn, Tuj1-positive cells contained hu $\alpha$-syn rarely (Fig. 3c), consistently with what we observed in our quantifications (Fig. 2e). In mice injected with tBSA, very rare Tuj1-positive cell contained BSA-positive punctae (Fig. 3d).

These data demonstrate that mitral/tufted cells, periglomerular cells as well as granular cells readily take up monomeric and oligomeric $t \alpha$-syn. Fibrillar $t \alpha$-syn is also taken up, but to a much lesser extent within the time frame of the experiment. The high degree of neuronal uptake of injected t $\alpha$-syn seems to be specific, as our control protein BSA was rarely taken up by neurons (Figs. 2a-d, 3d).

Monomeric and oligomeric t $\alpha$-syn appears in interconnected brain regions soon after injection into the olfactory bulb

\section{0 min post-injection}

After injecting monomeric or oligomeric t $\alpha$-syn into the $\mathrm{OB}$, we found hu $\alpha$-syn-positive cells in the ipsilateral AON and occasionally (in one animal out of 4) in the ipsilateral frontal cortex (FC). After fibrillar t $\alpha$-syn injections, we observed hu $\alpha$-syn-positive cells in the ipsilateral anterior AON only, in two mice out of four, event occurrence are summarized in supplementary Table 2, and immunohistochemistry results in supplementary Fig. 4. We did not observe BSA-positive signal in DAB in any non-OB brain region in control injections of tBSA.

\section{5 host-injection}

At the $1.5 \mathrm{~h}$ time point, in mice injected with monomeric or oligomeric $t \alpha$-syn in the OB, we detected hu $\alpha$-synpositive cells in several additional brain ipsilateral-regions: namely the AON, the FC, the tenia tecta (TT), the olfactory tubercle $(\mathrm{OTu})$, the piriform cortex $(\mathrm{PC})$, the striatum and the amygdala. Hu $\alpha$-syn-positive cells were also present in the contralateral hemisphere, specifically in the FC and the AON (Fig. 4). The hu $\alpha$-syn-positive cells displayed both a diffuse perikaryal staining as well as a punctae staining pattern. Importantly, in ipsilateral structures located distant from the OB, e.g. as the striatum and the amygdala, we detected a few hu $\alpha$-syn-positive cells (a few cells per region) (Fig. 4). Brains injected with fibrillar t $\alpha$-syn presented hu $\alpha$-syn-positive cells in the ipsilateral OB only (Fig. 4; supplementary Fig. 5a), suggesting that the fibrillar $\mathrm{t} \alpha$-syn was not transferred to any other brain region within $1.5 \mathrm{~h}$. In brains given control injections of tBSA, we found no BSA-positive cells either inside or outside the OB. We only observed a diffuse extracellular staining in the injected $\mathrm{OB}$ and in the anterior part of the AON. In supplementary Table 3, we present details of the distribution of hu $\alpha$-syn- and BSA-positive staining in each group at $1.5 \mathrm{~h}$. The quantification of hu $\alpha$-syn positive cells in groups injected with monomers and oligomers showed that the cells in anterior brain regions frequently exhibited hu $\alpha$-syn transfer. By contrast, in brain regions located further away from the OB (e.g. amygdala) the rate of huosyn transfer was low (Fig. 5a-d). Schematic drawings of coronal brain sections in supplementary Fig. 6a-c depict the overall load of hu $\alpha$-syn-positive cells in the different brain regions.

Importantly, to confirm our data from hu $\alpha$-syn staining at $1.5 \mathrm{~h}$ time point, we also performed a staining directed against the S-tag of t $\alpha$-syn. In each group of mice, we observed S-tag-positive cells in the same structures as with hu $\alpha$-syn staining. Thus the results obtained from S-tag detection are identical to the one from huo-syn staining (supplementary Fig. 7). Moreover, we confirm that the uptake by neurons and the transfer of huo-syn are not due to presence of the tags on hud-syn: injections of untagged monomeric huo-syn led the same distribution pattern as injections of tagged protein (supplementary Fig. 8; supplementary Table 3). 
Fig. 5 Quantifications of hu $\alpha$ syn-positive cells in different structures $1.5 \mathrm{~h}$ after injection into the OB. a Number of positive mitral cells in the ipsilateral $\mathrm{OB}$ at $90 \mathrm{~min}(H=9.846$, $P<0.01$, post hoc test: monomers/fibrils $P<0.01)$. Positive cells in the ipsilateral anterior olfactory nucleus (iAON), ipsilateral frontal cortex (iFC) (b); ipsilateral tenia tecta (iTT), olfactory tubercle (iOTu), piriform cortex (iPC), and striatum (iStr) (c); ipsilateral amygdala (iAm) and contralateral tenia tecta (cTT), anterior olfactory nucleus (cAON) and frontal cortex (cFC) (d). e Time evolution of $\alpha$-syn transfer and clearance in the ipsilateral piriform cortex. Scatter plots show data from individual mice. Black symbols represent animals that were excluded due technical issues during injection
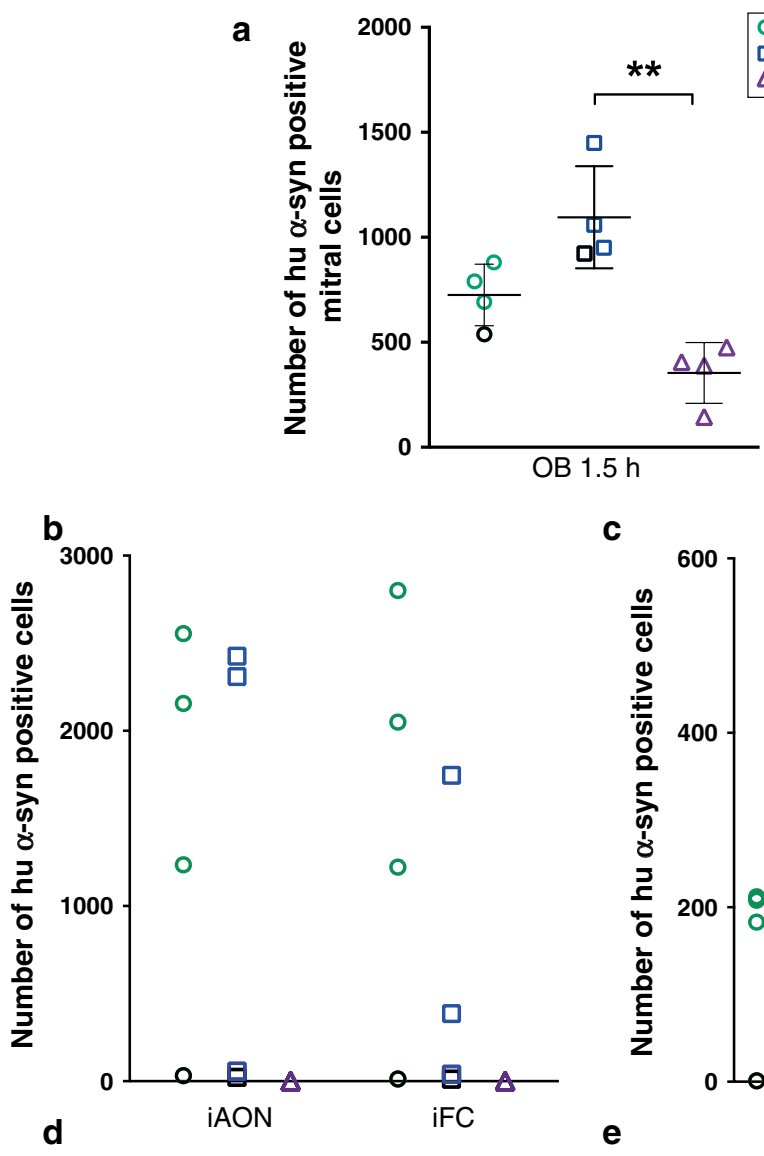

C
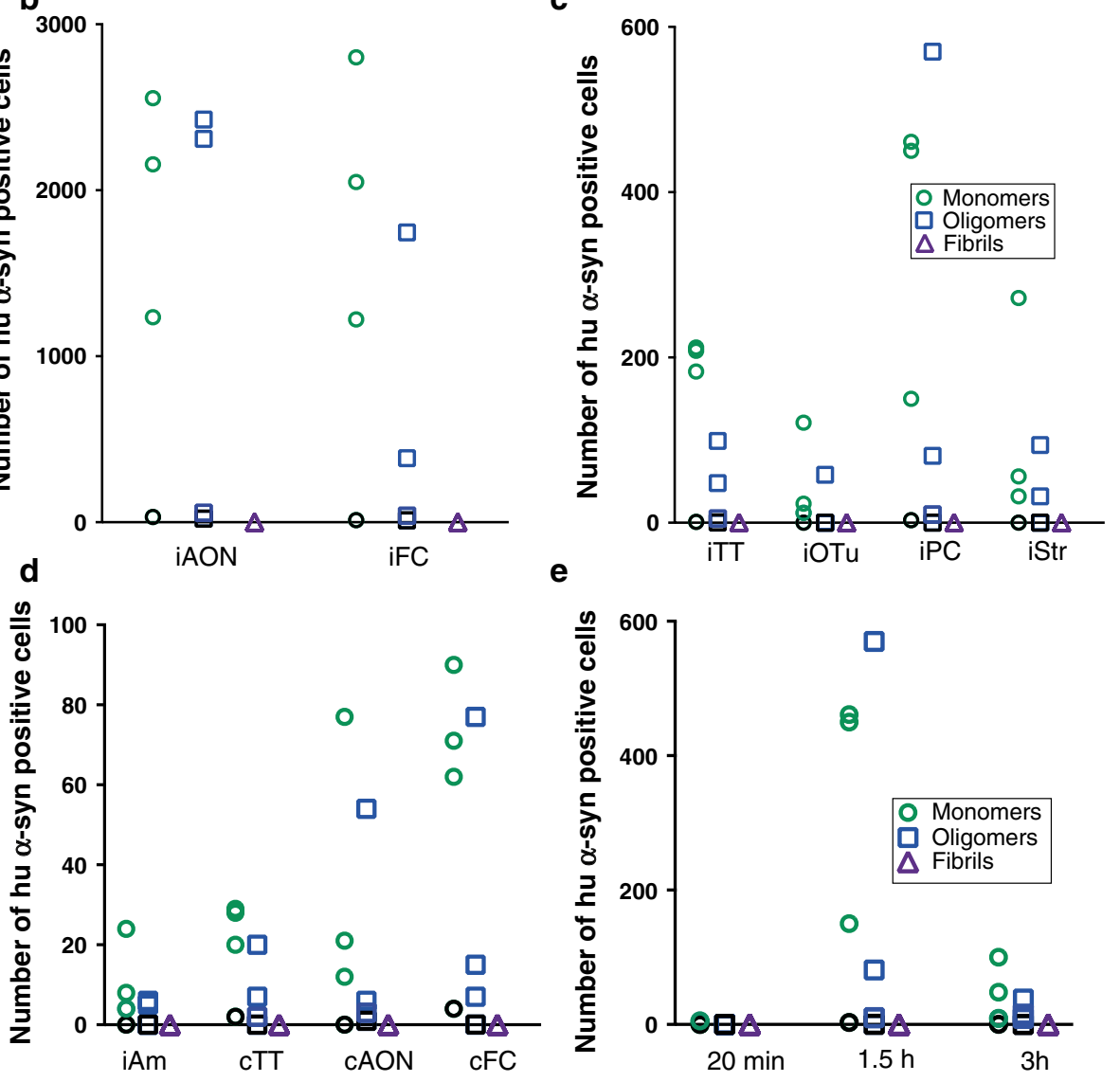

\section{3 h post-injection}

$3 \mathrm{~h}$ after injection of t $\alpha$-syn monomers and oligomers into the OB, we still detected hu $\alpha$-syn-positive cells in some of the structures mentioned above (the ipsilateral AON, FC, $\mathrm{TT}, \mathrm{OTu}, \mathrm{PC}$, and in the contralateral AON for monomers only). However, in contrast to the $1.5 \mathrm{~h}$ time point, we no longer found any hu $\alpha$-syn-positive cells in the ipsilateral amygdala, striatum and in contralateral FC (supplementary Fig. 9a; supplementary Table 4). In mice injected with fibrillar t $\alpha$-syn, we still detect hu $\alpha$-syn-positive cells in the OB only. By contrast, mice receiving control injections of tBSA exhibited only diffuse BSA staining in ipsilateral $\mathrm{OB}$ and in the very anterior part of ipsilateral AON, and we observed no positively stained cell bodies in any brain region (data not shown). In Fig. 6a, we present a schematic drawing summarizing the progression of protein spread in the brain within the time frames we examined. Quantification of the number of positive cells in the piriform cortex show that the highest rate of transfer of monomeric and oligomeric t $\alpha$-syn occurred within $1.5 \mathrm{~h}$, followed by a strong decrease in the number of positive cells after $3 \mathrm{~h}$ (Fig. 5e). In supplementary Fig. 6a-c, we present schematic drawings of coronal brain 
sections showing the distribution of hu $\alpha$-syn-positive cells throughout the brain.

To control that the t $\alpha$-syn we detected in brain regions far from the OB was not likely to be due to diffusion of the injected solution via the cerebrospinal fluid, we injected the same volume $(0.8 \mu \mathrm{l})$ of monomeric t $\alpha$-syn in the lateral ventricle (LV), or on the top of the OB, into the subarachnoid space. We killed mice $3 \mathrm{~h}$ after injection, and

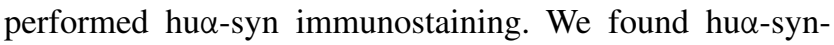
positive cells around the injection site in the overlying cortex when the solution was injected into the LV. None of the brain structures mentioned above exhibited huo-synpositive cells (AON, FC, PC, striatum, amygdala shown in supplementary Fig. 9b; supplementary Table 5). When we injected $t \alpha$-syn on the top of the OB (in the subarachnoid space, we observed hu $\alpha$-syn-positive staining $3 \mathrm{~h}$ later only on the superficial part of the olfactory nerve at the level of injection. Thus we found no huo-syn-positive cells in the brain (negative staining in the $\mathrm{OB}, \mathrm{AON}, \mathrm{FC}, \mathrm{PC}$, striatum, amygdala shown in supplementary Fig. 9b; supplementary Table 5). These controls strongly suggest that t $\alpha$-syn present in cells far from the OB is not the result of a diffusion of injected t $\alpha$-syn through the cerebrospinal fluid. Taken together, our results suggest that after injection into the $\mathrm{OB}$, monomeric and oligomeric t $\alpha$-syn is taken up by neurons locally and rapidly spreads from the OB to other brain structures.

More than $12 \mathrm{~h}$ after injection into the olfactory bulb, $\alpha$-synuclein is present in neurons and microglia locally, as well as in microglia in interconnected brain regions

We also investigated the localization of t $\alpha$-syn at two later time points, 12 and $72 \mathrm{~h}$ post-injection.

\section{2 h post-injection}

After injections of monomers and fibrils into the $\mathrm{OB}$, we detected $t \alpha$-syn in cells with a microglia-like shape in the ipsilateral OB and FC; and occasionally in the AON, in one to two animals out of four. After injection of oligomers, we observed huo-syn-positive cells with microglia-like shape in the ipsilateral OB, FC and AON (Fig. 6b; supplementary Table 6). Interestingly, in the mice that received injections of oligomers or fibrils into the OB, we also identified hu $\alpha$ syn-positive mitral and tufted cells, based on their shape and precise localization using DAB staining (Fig. 6b, representative sketches in supplementary Fig. 6b, c).

We confirmed the presence of t $\alpha$-syn in the perikarya of microglia in the OB by immunofluorescent staining for Iba1 after injection of monomeric (Fig. 7a), oligomeric (Fig. 7b) and fibrillar t $\alpha$-syn (Fig. 7c). Rarely we found microglial cells containing BSA-positive punctae (detected with its ATTO-550 tag) (Fig. 7d) $12 \mathrm{~h}$ after injection of tBSA.

\section{2 h post-injection}

At $72 \mathrm{~h}$ after injection of t $\alpha$-syn monomers, oligomers and fibrils, we observed heavily hu $\alpha$-syn-positive microglia cells in the ipsilateral $\mathrm{OB}$ and $\mathrm{FC}$, as well as the ipsilateral AON (Fig. 6c; supplementary Table 7). Again, we confirmed the presence of t $\alpha$-syn (detected using ATTO-550 tag) in the perikarya of microglia in the OB by immunofluorescence after injection of t $\alpha$-syn (Fig. 8d).

\section{Recruitment of microglia in the $O B 1.5 \mathrm{~h}$ after injection of $t \alpha-s y n$}

The first microglial cells appear in the OB around the injection site $1.5 \mathrm{~h}$ after injection of oligomeric t $\alpha$-syn. While we could not detect Iba1-positive cells at $20 \mathrm{~min}$ (Fig. 8a), we observed $t \alpha$-syn in the perikarya of microglia in the $\mathrm{OB}$ at later timepoints, from 1.5 to $72 \mathrm{~h}$ after injection (Fig. 8b-d).

\section{Discussion}

Here we demonstrate that hu $\alpha$-syn is taken up by neurons in the OB and can also be rapidly transferred to interconnected brain regions. Specifically, local OB interneurons as well as mitral/tufted cells (relay cells of the OB that project to further olfactory structures) readily take up monomeric and oligomeric hu $\alpha$-syn. The same neurons also take up fibrillar hu $\alpha$-syn, but to a much lesser extent. The OB cells also take up tBSA, but to a lesser degree, suggesting that monomeric and oligomeric hu $\alpha$-syn are readily taken up and subject to transfer to other brain regions. Consistent with previous observations made in vitro [41], $\alpha$-syn low molecular species are rapidly taken up resulting in some OB cells being positive for hu $\alpha$-syn already $20 \mathrm{~min}$ after injection.

Non-specific/passive diffusion probably plays a minor role in spreading of $\alpha$-synuclein in the brain

We performed different control injections and the results showed that it is highly unlikely that the injected material diffuses away from the OB via the brain parenchyma or the cerebrospinal fluid and thereby contributes to the spread of injected hu $\alpha$-syn to other brain regions. Therefore the huosyn we observed in neurons in brain regions distant from the OB is more likely to have been transported intracellularly via neural projections, considering the pattern of transfer to structures interconnected with the OB. 


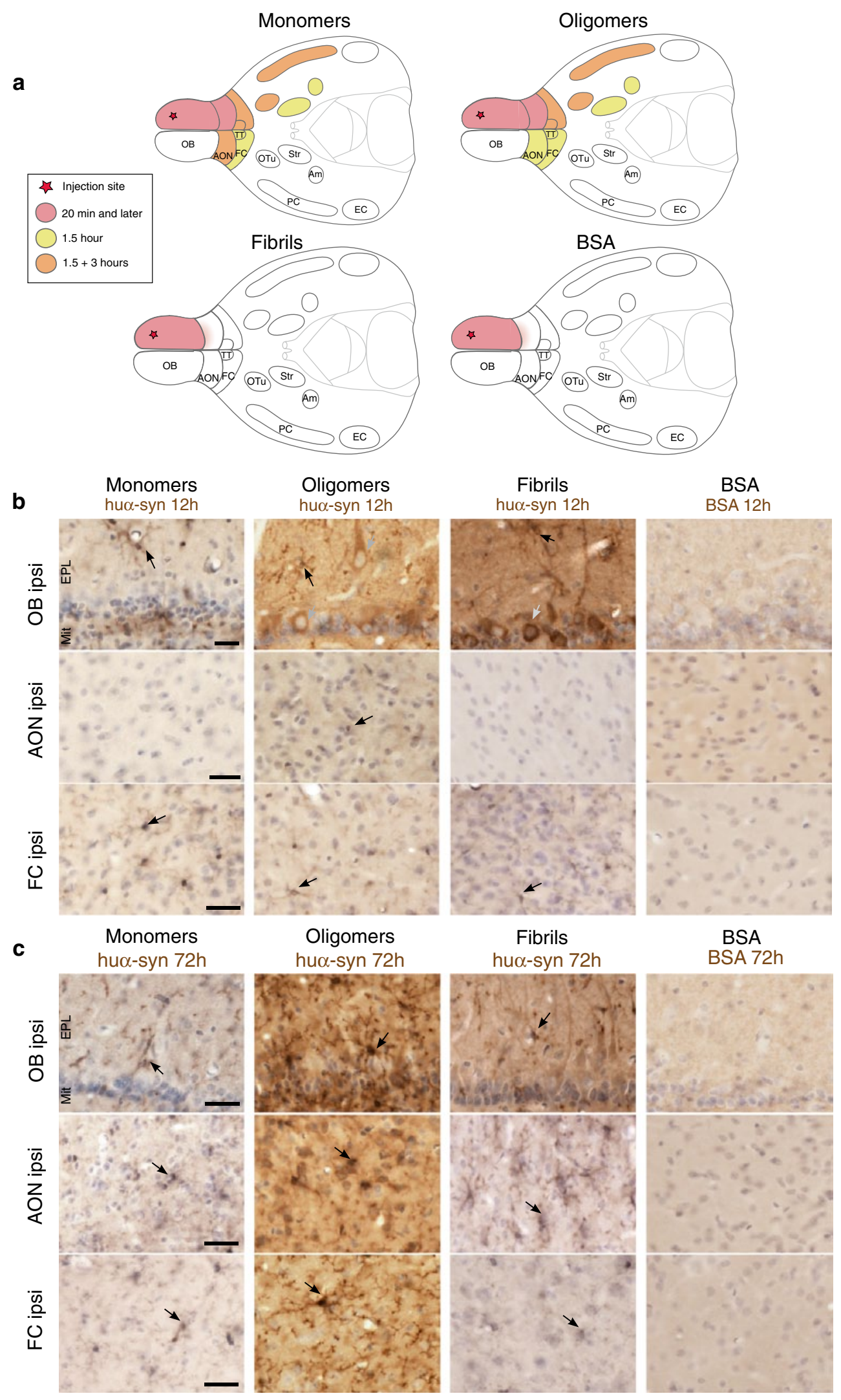


4 Fig. 6 Temporal evolution of $t \alpha$-syn presence in the brain after injection in the OB. a Drawings representing schematic horizontal sections of the brain with the different regions exhibiting hu $\alpha$-synpositive cells or a diffuse BSA-staining at different time points after protein injection in the OB. b BSA and hu $\alpha$-syn staining $12 \mathrm{~h}$ after injection in the OB. We detected hu $\alpha$-syn-positive cells in the ipsilateral $\mathrm{OB}$, and $\mathrm{FC}$ after injection of monomeric, oligomeric and fibrillar $\mathrm{t} \alpha$-syn, as well as in the ipsilateral AON after injection of oligomers. On the contrary, we did not find BSA-positive cells in the brain $12 \mathrm{~h}$ after tBSA injection in the OB. Hu $\alpha$-syn-positive cells appeared to be either mitral/tufted cells, located in the external plexiform (EPL) and mitral cell (Mit) layers of the OB (in groups injected with oligomers or fibrils, grey arrows), or displayed the morphology of microglial cells (in groups injected with monomers, oligomers or

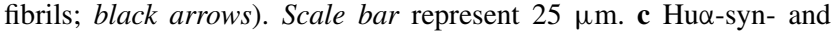
BSA-staining $72 \mathrm{~h}$ after injection in the OB. Hu $\alpha$-syn-positive cells were detected in the ipsilateral $\mathrm{OB}, \mathrm{AON}$ and $\mathrm{FC}$ after injection of monomers, oligomers and fibrils $72 \mathrm{~h}$ after injection, and those cells exhibit a microglia-like morphology. On the contrary, no BSA-positive cell was found in the brain $72 \mathrm{~h}$ after tBSA injection in the OB. Scale bar represents $25 \mu \mathrm{m}$

Regarding the different molecular species of hu $\alpha$-syn we used, we observed clear differences in the transfer of fibrils and monomers/oligomers. We found that monomers and oligomers are taken up by neurons in the OB and are rapidly transported to other brain regions. In contrast, fibrils are taken up by fewer neurons in the $\mathrm{OB}$ and they are not transferred at detectable levels to other brain regions within $72 \mathrm{~h}$.

In vitro, the internalization of fibrils by neurons is slower than that of soluble $\alpha$-syn and can take several hours [41]. This relatively slow uptake of fibrils, combined with a rapid and efficient clearance of extracellular huo-syn by microglia, could limit the load of fibrils that are taken up by neurons.

Alternative spreading mechanisms to intra-axonal transport

Our data suggest that the injected huo-syn does not spread via the cerebrospinal fluid. We cannot, however, rule out the involvement of other mechanisms in hu $\alpha$-syn spread from the OB. Entry of huo-syn into the blood circulation by physically damaged vessels at the injection site, and transport of hu $\alpha$-syn via blood vessels is one such option. In the mouse, huo-syn injected intravenously has a half-life of about $1 \mathrm{~h} \mathrm{[37].} \mathrm{However,} \mathrm{there} \mathrm{is} \mathrm{no} \mathrm{spread} \mathrm{to} \mathrm{structures}$ that are not connected via neural pathways to the $\mathrm{OB}$, suggesting that vascular transfer is not involved. Another possibility is hu $\alpha$-syn is engulfed by microglial cells [4, 64] that then migrate from one brain region to another. If the hu $\alpha$-syn is not successfully degraded by the microglia it is conceivable that it is released into the extracellular space and then is taken up by adjacent cells. Once again, however, then one would not expect to find hu $\alpha$-syn positive neurons only in regions directly connected via neural pathways to the OB. Finally, two other alternative mechanisms to microtubule-dependent intracellular transport that could explain the specific pattern in interconnected regions need to be considered. Either simple diffusion of hu $\alpha$-syn within the neuronal cytoplasm could play a role, or myosin-actin-dependent transport [9], that is reported to support transport (of organelles) within axons and dendrites, is operative. For both these mechanisms, however, the speed of transport is too low to explain our observations. Furthermore, short actin filaments are more likely to contribute to short-distance intra-neuronal transport as opposed to longrange axonal transport [9].

\section{Direction of $\alpha$-synuclein transfer}

Several in vitro and in vivo studies strongly suggest that $\alpha$-syn can be released by cultured cells or neurons in vivo and taken up from the culture medium or from extracellular compartment by neighboring cells $[2,19,25,29]$. In addition, other in vitro studies have demonstrated that $\alpha$-syn is transported within the axon of a recipient neuron in both anterograde and retrograde directions [25, 61]. Therefore, if the spread of hu $\alpha$-syn we observe is due to an axonal transport from the $\mathrm{OB}$ to interconnected region, transport along axons in both directions, combined with cell-to-cell transfer at synaptic sites, could explain why we observed hu $\alpha$-syn in brain regions outside the OB.

First, with this hypothesis in mind, let us consider that hu $\alpha$-syn undergoes anterograde axonal transport from the OB in our paradigm (see Fig. 9), a notion consistent with the dual-hit hypothesis [31]. Almost every structure where we detected hu $\alpha$-syn-positive neurons receives direct axonal projections from OB mitral/tufted cells (ipsilateral AON, TT, OTu, PC, amygdala; [12, 28, 33, 48]). Thus, it is possible that the injected hu $\alpha$-syn underwent anterograde transport from the $\mathrm{OB}$ to these structures within the axons of mitral/tufted cells, and then transferred from the axon termini to the target neurons. Regarding the brain structures that lack direct axonal projections from the OB but that still exhibited huo-syn-positive neurons (ipsilateral striatum, contralateral AON and both ipsilateral and contralateral FC), anterograde transport in two steps could explain the spread we observed. For example, the hu $\alpha$ syn might have been transported via the PC/amygdala to the striatum, followed by a cell-to-cell transfer to striatal neurons.

Second, still in the light of a possible intra-axonal transfer, hu $\alpha$-syn could also have been transported retrogradely from the $\mathrm{OB}$ to connected brain regions. The OB receives projections from almost all the structures where we detected huo-syn, namely the AON bilaterally $[34,54]$, FC [14], ipsilateral PC and OTu [47] and the ipsilateral TT [15, 52]. Thus, retrograde transport along axons to cell bodies 

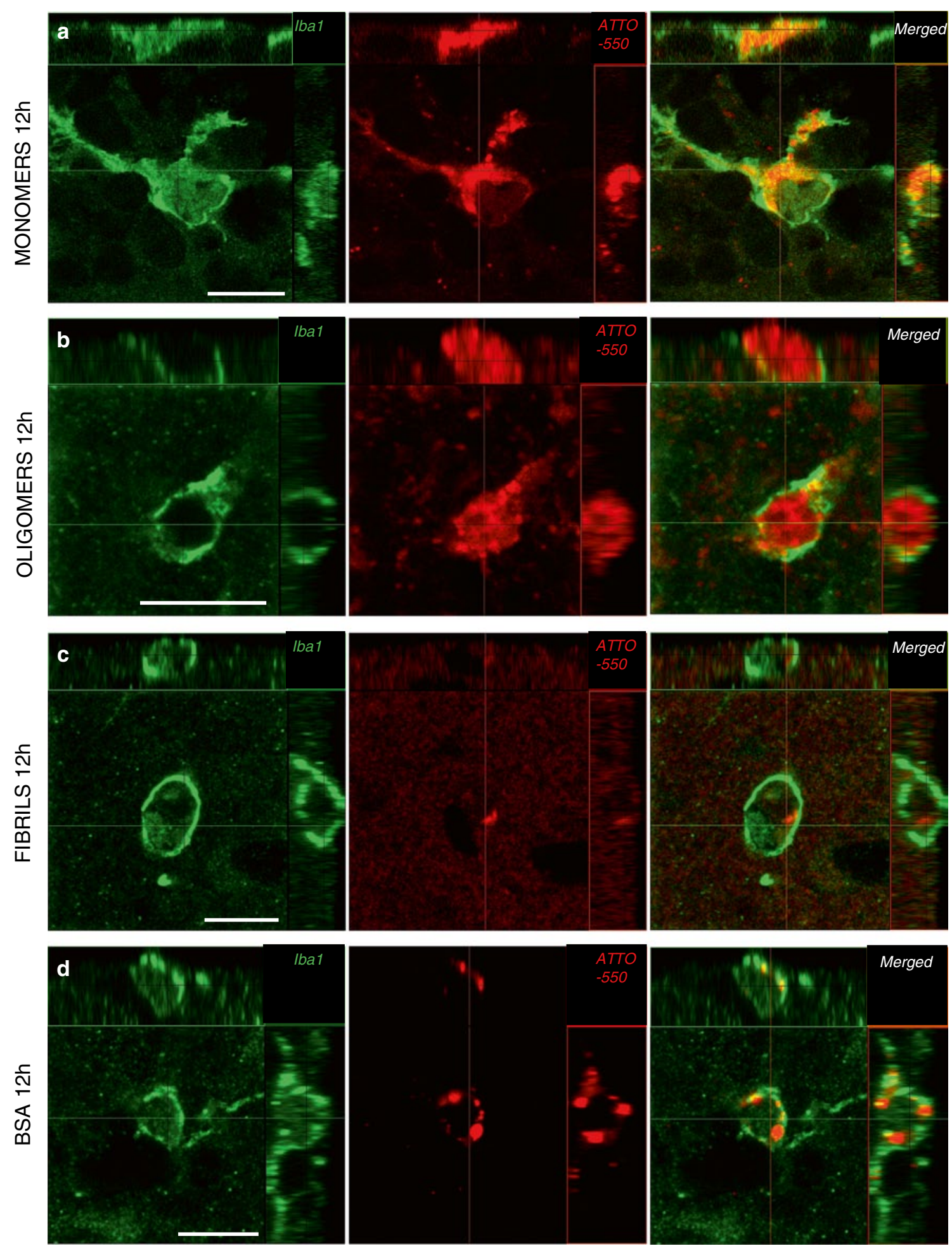

Fig. $7 \mathrm{~T} \alpha$-syn is localized within microglia $12 \mathrm{~h}$ after injection into the OB. Sections were stained by immunofluorescence for Iba1 (green), a microglial marker. T $\alpha$-syn and tBSA were identified by their ATTO-550 fluorescent tag (red). Confocal three-dimensional reconstructions show ATTO-550 signal (red) colocalized with Iba1 (green) within microglia in the $\mathrm{OB}$ of mice injected with monomers (a), oligomers (b) and fibrils (c), indicating that these microglial cells contain hu $\alpha$-syn. We also detected ATTO-550 signal in Iba1-positive cells in mice injected with the control protein tBSA (d). Scale bars represent $10 \mu \mathrm{m}$ in each panel 

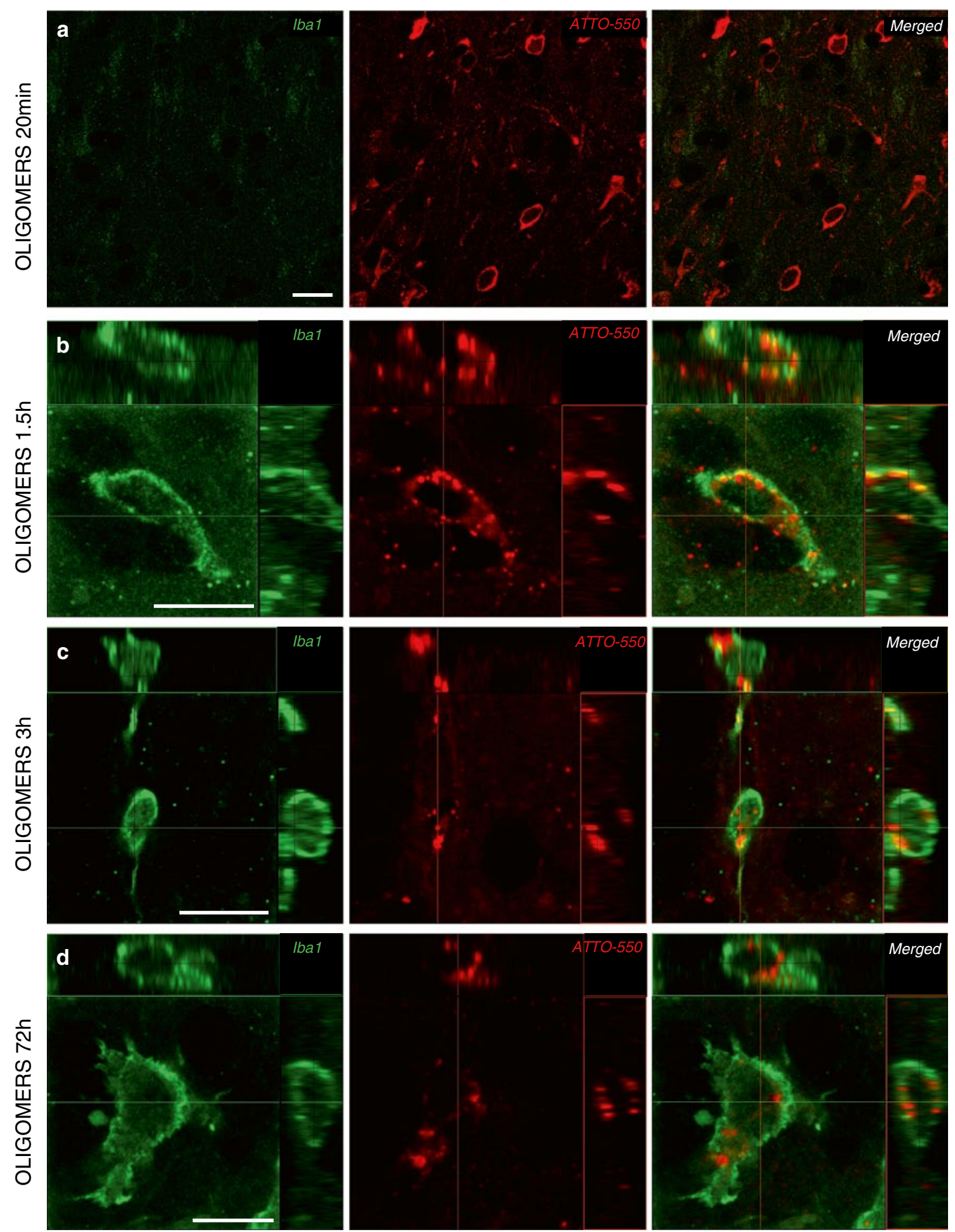

Fig. $8 \mathrm{~T} \alpha$-syn is localized within microglia already $1.5 \mathrm{~h}$ after injection into the OB. T $\alpha$-syn was identified by its ATTO-550 fluorescent tag (red), and microglial cells by Ibal staining (green) by confocal microscopy. At 20 min after injection of oligomers, no Iba1-positive cell containing ATTO-550 signal was detected (a). After $1.5 \mathrm{~h}$, con- focal three-dimensional reconstructions show ATTO-550 signal (red) colocalized with Iba1 (green) also within microglia in the OB of mice injected with oligomers at $1.5 \mathrm{~h} \mathrm{(b),} 3 \mathrm{~h}$ (c) and $72 \mathrm{~h} \mathrm{(d)} \mathrm{timepoints,}$ indicating that these cells contain huo-syn. Scale bars represent $10 \mu \mathrm{m}$ in each panel 
Fig. 9 Schematic diagram summarizing both the olfactory neural network and regions where hu $\alpha$-syn-positive cells are detected after injection into the OB. This schematic horizontal section of the brain illustrate some of the important regions connected to the OB. Red, green, yellow and blue pathways schematically represent connections within the olfactory system. Circular endpoint of pathways represents the cell body of a relay neuron and a strait end represents the axonal terminal. Structures filled with grey represent regions that displayed hu $\alpha$-syn-positive cells $1.5 \mathrm{~h}$ after injection of monomeric and oligomeric t $\alpha$-syn. All those regions are directly, or indirectly connected to the OB by centrifugal or centripetal projections

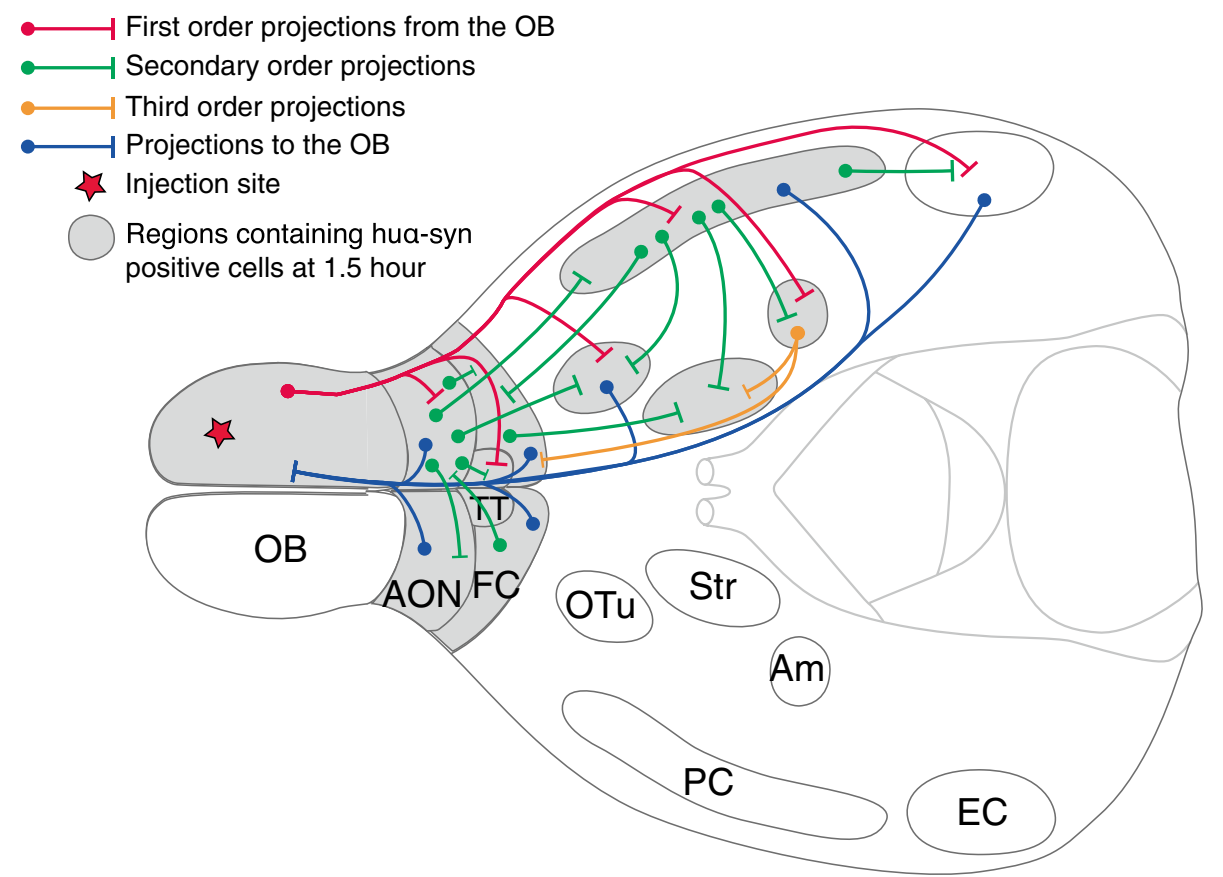

located in these aforementioned regions (AON, FC, PC, OTu, TT) is plausible.

We also found labeled protein in two brain regions that do not project to the $\mathrm{OB}$, i.e. the amygdala and striatum. The huo-syn in the amygdala could be the result of direct retrograde transport from the accessory $\mathrm{OB}$ along axons originating in the amygdala [53]. Alternatively, the huosyn underwent retrograde transport from the $\mathrm{OB}$ to, e.g. the ipsilateral FC and transcended one synapse before undergoing further retrograde transport to the amygdala [40]. Thus, for all the structures cited above, both anterograde or/and retrograde transport(s) are conceivable. In some cases, the locations in which we found hu $\alpha$-syn require that the protein had transcended at least one synapse. The hu $\alpha$-syn we found in the striatum cannot be the result of retrograde transport due to the lack of direct (or indirect) projections from the striatum to the OB. Thus, if and intra-axonal transport to the striatum occurred, it can only be via anterograde transport with a transsynaptic step before reaching striatal neurons.

Finally, the entorhinal cortex, which receives direct projections from the OB, did not contain any hu $\alpha$-synpositive cells. The transfer to the entorhinal cortex might require more than $1.5 \mathrm{~h}$ considering the long distance between the entorhinal cortex and the $\mathrm{OB}$, and transferred protein may be cleared from the cells before the next $(3 \mathrm{~h})$ time point we studied. Another explanation could be that the concentration of transferred hu $\alpha$-syn might be below DAB staining threshold. Alternatively, hu $\alpha$-syn may be either taken up inefficiently by neurons from the entorhinal cortex.
Speed of $\alpha$-synuclein spread is compatible with intra-axonal transport

At $1.5 \mathrm{~h}$ after injection into the OB, we observed hu $\alpha$-syn in structures located at $4.8 \mathrm{~mm}$ maximum distance from the posterior limit of injected area in the OB (maximal speed $3.2 \mathrm{~mm} / \mathrm{h}$ ). At $20 \mathrm{~min}$ after injection, hu $\alpha$-syn reaches areas located less than $0.6 \mathrm{~mm}$ approximately caudal to the diffusion area in the OB (maximal speed $1.8 \mathrm{~mm} / \mathrm{h}$ ). From the perspective of axonal transport, this range of speeds is compatible with both retrograde $(4-8 \mathrm{~mm} / \mathrm{h})$ and fast anterograde transport $(2.1-16.6 \mathrm{~mm} / \mathrm{h}$ ) (reviewed in $[10$, $51,55]$. In fact, $15-26 \%$ of slow component $\mathrm{b}$ particles and $\alpha$-syn can be transported via fast axonal transport [36, 56], and thus might account for the presence of hu $\alpha$-syn in structures that are relatively distant from the OB.

Rapid disappearance of injected $\alpha$-synuclein from neurons

At $3 \mathrm{~h}$ after injection, no additional (compared to the $1.5 \mathrm{~h}$ time point) brain regions contained hu $\alpha$-syn. In some of the structures where the staining obtained $1.5 \mathrm{~h}$ after injection was very discrete, it had disappeared at the $3 \mathrm{~h}$ time point. At that time, no hu $\alpha$-syn was detectable in the amygdala, striatum and brain regions further downstream. At $12 \mathrm{~h}$, but not at $72 \mathrm{~h}$ a few hu $\alpha$-syn-positive neurons were still present in OBs injected with oligomers and fibrils. Interestingly, we also detected hu $\alpha$-syn-positive microglia in the OB, AON and FC. These were rare at 1.5 and $3 \mathrm{~h}$, but prevalent at 12 and $72 \mathrm{~h}$. Taken together, these data support the idea that the hu $\alpha$-syn is gradually cleared from the 
neurons. It is likely that hu $\alpha$-syn is released to the extracellular space by neurons, or that some neurons containing hu $\alpha$-syn died, leading to the hu $\alpha$-syn (free or bound to cellular debris) being cleared by microglia [42].

Relevance of $\alpha$-synuclein transfer to the spread of Lewy pathology in patients

Regarding the spatial evolution of Lewy pathology in PD brains, Braak and co-workers $[6,8]$ proposed that synucleinopathy starts in the $\mathrm{OB}$ and $\mathrm{AON}$, and/or in the dorsal motor nucleus of the vagus nerve; and then spreads to others structures along neural connections [6-8, 31, 32].

The first hints that such a progression of neuropathology is plausible are now coming from animal models of PD. For example, Ulusoy et al. [60] recently reported caudo-rostral spreading of $\alpha$-syn in the medulla oblongata following injection of adeno-associated viral vector expressing hu $\alpha$-syn into the vagus nerve. Moreover, Luk et al. [43] recently demonstrated in mice that injections of pathologically misfolded $\alpha$-syn into the striatum induce a PD-like pathology in different brain regions, along with motor dysfunction and dopaminergic nigral cell loss. The pathology took months to develop and was initiated by injecting hu $\alpha$-syn in the striatum, i.e. a brain structure that is not affected early in PD. Importantly, we investigated in a very short time-frame, the transfer of hu $\alpha$-syn itself, from the OB, which is thought to be one of the two regions affected first in $\mathrm{PD}$, to other brain regions $[6,8]$. We know now that hu $\alpha$-syn can be transferred from the OB of WT mice to interconnected regions, within a very short time frame and is cleared very efficiently, presumably by microglia. Although others have found that certain forms of preformed $\alpha$-syn fibrils can trigger a PD-like pathology in mouse brain [43, 44, 46], we saw no Lewy-like bodies after injecting our hu $\alpha$-syn fibrils into the OB. Differences in the dose and the nature of the injected form of $\alpha$-syn, e.g. monomers vs oligomers vs fibrils, as well as differences in the duration of the experiment, could explain why we did not observe the formation of Lewy-like bodies. Alternatively, the mouse OB might handle $\alpha$-syn fibrils differently to the striatum. Interestingly, the role of $\alpha$-syn oligomers in PD is also highly debated $[38,39]$, and some recent studies suggest that this form of $\alpha$-syn is particularly toxic [19, 23, 63] and plays a key intermediary role in $\alpha$-syn fibrillization [3]. A recent paper suggests that specifically $\alpha$-syn oligomers, but not monomers and fibrils, disturb membrane trafficking when cultivated cells are exposed to them in the culture medium [13]. With this background, the high propensity of oligomers to spread between brain regions, which we observed in our model, may be important also in a disease context. We observed that monomeric and oligomeric $\alpha$-syn can be transferred to interconnected regions. From that, we can speculate that a pathological seed of $\alpha$-syn in the same range of size as our monomers-oligomers could also be transferred in an identical manner to interconnected regions. Moreover, if the $\alpha$-syn escapes from proteostatic clearance, it can slowly recruit other proteins (including $\alpha$ syn from the recipient cell) and thereby contribute to the spread of synucleinopathy within the brain.

\section{Conclusion}

We have demonstrated for the first time that hu $\alpha$-syn injected into the $\mathrm{OB}$ is taken up by neurons and transferred to interconnected brain regions. This transfer is consistent with anterograde and/or retrograde axonal transport as well as cell-to-cell transfer. Our data support the concept that $\alpha$-syn (main component of Lewy bodies) can spread from the $\mathrm{OB}$, one of the first structures affected in $\mathrm{PD}$ according to Braak and collaborators, to interconnected brain regions.

Acknowledgments This work was supported by the European Research Council (PRISTINE-PD 269064 to P.B.), the Swedish Research Council (K2010-61X-11286-16-3 to P.B.), the Parkinson Foundation (Sweden) (416/11 to P.B.), the Human Frontier Science Program (RGP0022/2009-C to P.B.), the Centre National de la Recherche Scientifique, and the Agence Nationale de la Recherche (ANR-09-MNPS-013-01 to R.M.) and a "Coup d'Élan à la Recherche Française" award from the Fondation Bettencourt Schueller. N.R, G.H.P. and P.B. are active in the Strategic Research Area Multipark (Multidisciplinary research in Parkinson's disease at Lund University), and N.R. is recipient of personal grants from this program. We thank Alicja Flasch, Birgit Haraldsson and Marie Persson-Vejgården for their technical assistance.

Conflict of interest The authors declare that they have no conflict of interest.

Open Access This article is distributed under the terms of the Creative Commons Attribution License which permits any use, distribution, and reproduction in any medium, provided the original author(s) and the source are credited.

\section{References}

1. Angot E, Brundin P (2009) Dissecting the potential molecular mechanisms underlying alpha-synuclein cell-to-cell transfer in Parkinson's disease. Park Relat Disord 15(Suppl 3):S143-S147

2. Angot E, Steiner JA, Lema Tome CM, Ekstrom P, Mattsson B, Bjorklund A, Brundin P (2012) Alpha-synuclein cell-to-cell transfer and seeding in grafted dopaminergic neurons in vivo. PLoS One 7(6):e39465

3. Ariesandi W, Chang CF, Chen TE, Chen YR (2013) Temperaturedependent structural changes of Parkinson's alpha-synuclein reveal the role of pre-existing oligomers in alpha-synuclein fibrillization. PLoS One 8(1):e53487

4. Bae EJ, Lee HJ, Rockenstein E, Ho DH, Park EB, Yang NY, Desplats P, Masliah E, Lee SJ (2012) Antibody-aided clearance 
of extracellular alpha-synuclein prevents cell-to-cell aggregate transmission. J Neurosci 32(39):13454-13469

5. Braak H, Del Tredici K (2004) Poor and protracted myelination as a contributory factor to neurodegenerative disorders. Neurobiol Aging 25(1):19-23

6. Braak H, Del Tredici K, Rub U, de Vos RA, Jansen Steur EN, Braak E (2003) Staging of brain pathology related to sporadic Parkinson's disease. Neurobiol Aging 24(2):197-211

7. Braak H, Ghebremedhin E, Rub U, Bratzke H, Del Tredici K (2004) Stages in the development of Parkinson's disease-related pathology. Cell Tissue Res 318(1):121-134

8. Braak H, Rub U, Gai WP, Del Tredici K (2003) Idiopathic Parkinson's disease: possible routes by which vulnerable neuronal types may be subject to neuroinvasion by an unknown pathogen. J Neural Transm 110(5):517-536

9. Bridgman PC (2004) Myosin-dependent transport in neurons. J Neurobiol 58(2):164-174

10. Brown A (2003) Axonal transport of membranous and nonmembranous cargoes: a unified perspective. J Cell Biol 160(6):817-821

11. Brundin P, Li JY, Holton JL, Lindvall O, Revesz T (2008) Research in motion: the enigma of Parkinson's disease pathology spread. Nat Rev 9(10):741-745

12. Canavan SV, Mayes LC, Treloar HB (2011) Changes in maternal gene expression in olfactory circuits in the immediate postpartum period. Front Psychiatry 2:40

13. Chai YJ, Kim D, Park J, Zhao H, Lee SJ, Chang S (2013) The secreted oligomeric form of alpha-synuclein affects multiple steps of membrane trafficking. FEBS Lett

14. Cinelli AR, Ferreyra-Moyano H, Barragan E (1987) Reciprocal functional connections of the olfactory bulbs and other olfactory related areas with the prefrontal cortex. Brain Res Bull 19(6):651-661

15. Cleland TA, Linster C (2003) Central olfactory structures. In: Doty RL (ed) Handbook of olfaction and gustation. Marcel Dekker, New York, pp 165-181

16. Conway KA, Harper JD, Lansbury PT Jr (2000) Fibrils formed in vitro from alpha-synuclein and two mutant forms linked to Parkinson's disease are typical amyloid. Biochemistry 39(10):2552-2563

17. Conway KA, Lee SJ, Rochet JC, Ding TT, Williamson RE, Lansbury PT Jr (2000) Acceleration of oligomerization, not fibrillization, is a shared property of both alpha-synuclein mutations linked to early-onset Parkinson's disease: implications for pathogenesis and therapy. Proc Natl Acad Sci USA 97(2):571-576

18. Danzer KM, Krebs SK, Wolff M, Birk G, Hengerer B (2009) Seeding induced by alpha-synuclein oligomers provides evidence for spreading of alpha-synuclein pathology. J Neurochem 111(1):192-203

19. Desplats P, Lee HJ, Bae EJ, Patrick C, Rockenstein E, Crews L, Spencer B, Masliah E, Lee SJ (2009) Inclusion formation and neuronal cell death through neuron-to-neuron transmission of alpha-synuclein. Proc Natl Acad Sci USA 106(31):13010-13015

20. Doty RL (2012) Olfaction in Parkinson's disease and related disorders. Neurobiol Dis 46(3):527-552

21. Doty RL (2012) Olfactory dysfunction in Parkinson disease. Nat Rev Neurol 8(6):329-339

22. Dunning CJ, Reyes JF, Steiner JA, Brundin P (2012) Can Parkinson's disease pathology be propagated from one neuron to another? Prog Neurobiol 97(2):205-219

23. Emmanouilidou E, Melachroinou K, Roumeliotis T, Garbis SD, Ntzouni M, Margaritis LH, Stefanis L, Vekrellis K (2010) Cellproduced alpha-synuclein is secreted in a calcium-dependent manner by exosomes and impacts neuronal survival. J Neurosci 30(20):6838-6851
24. Fauvet B, Mbefo MK, Fares MB, Desobry C, Michael S, Ardah MT, Tsika E, Coune P, Prudent M, Lion N, Eliezer D, Moore DJ, Schneider B, Aebischer P, El-Agnaf OM, Masliah E, Lashuel HA (2012) Alpha-synuclein in central nervous system and from erythrocytes, mammalian cells, and Escherichia coli exists predominantly as disordered monomer. J Biol Chem 287(19):15345-15364

25. Freundt EC, Maynard N, Clancy EK, Roy S, Bousset L, Sourigues Y, Covert M, Melki R, Kirkegaard K, Brahic M (2012) Neuron-to-neuron transmission of alpha-synuclein fibrils through axonal transport. Ann Neurol 72(4):517-524

26. Ghee M, Melki R, Michot N, Mallet J (2005) PA700, the regulatory complex of the $26 \mathrm{~S}$ proteasome, interferes with alpha-synuclein assembly. FEBS J 272(16):4023-4033

27. Goedert M (2001) Alpha-synuclein and neurodegenerative diseases. Nat Rev 2(7):492-501

28. Gottfried JA, Wilson DA (2011) Smell In: Gottfried JA (ed) Neurobiology of sensation and reward. CRC Press, Boca Raton, FL

29. Hansen C, Angot E, Bergstrom AL, Steiner JA, Pieri L, Paul G, Outeiro TF, Melki R, Kallunki P, Fog K, Li JY, Brundin P (2011) Alpha-synuclein propagates from mouse brain to grafted dopaminergic neurons and seeds aggregation in cultured human cells. J Clin Invest 121(2):715-725

30. Hardy J (2005) Expression of normal sequence pathogenic proteins for neurodegenerative disease contributes to disease risk: 'permissive templating' as a general mechanism underlying neurodegeneration. Biochem Soc Trans 33(Pt 4):578-581

31. Hawkes CH, Del Tredici K, Braak H (2007) Parkinson's disease: a dual-hit hypothesis. Neuropathol Appl Neurobiol 33(6):599-614

32. Hawkes CH, Del Tredici K, Braak H (2010) A timeline for Parkinson's disease. Park Relat Disord 16(2):79-84

33. Hintiryan H, Gou L, Zingg B, Yamashita S, Lyden HM, Song MY, Grewal AK, Zhang X, Toga AW, Dong HW (2012) Comprehensive connectivity of the mouse main olfactory bulb: analysis and online digital atlas. Front Neuroanat 6:30

34. Illig KR, Eudy JD (2009) Contralateral projections of the rat anterior olfactory nucleus. J Comp Neurol 512(1):115-123

35. Irwin DJ, Abrams JY, Schonberger LB, Leschek EW, Mills JL, Lee VM, Trojanowski JQ (2013) Evaluation of potential infectivity of Alzheimer and Parkinson disease proteins in recipients of cadaver-derived human growth hormone. JAMA Neurol 70(4):462-468

36. Jensen PH, Li JY, Dahlstrom A, Dotti CG (1999) Axonal transport of synucleins is mediated by all rate components. Eur J Neurosci 11(10):3369-3376

37. Jonsson O, Steffen AC, Sundquist VS, Janson J, Martinsson S, Maatta U, Emanuelsson AB (2013) Capillary microsampling and analysis of 4- $\mu$ blood, plasma and serum samples to determine human alpha-synuclein elimination rate in mice. Bioanalysis 5(4):449-462

38. Kalia LV, Kalia SK, McLean PJ, Lozano AM, Lang AE (2012) Alpha-synuclein oligomers and clinical implications for Parkinson disease. Ann Neurol

39. Kazantsev AG, Kolchinsky AM (2008) Central role of alphasynuclein oligomers in neurodegeneration in Parkinson disease. Arch Neurol 65(12):1577-1581

40. Kita H, Kitai ST (1990) Amygdaloid projections to the frontal cortex and the striatum in the rat. J Comp Neurol 298(1):40-49

41. Lee HJ, Suk JE, Bae EJ, Lee JH, Paik SR, Lee SJ (2008) Assembly-dependent endocytosis and clearance of extracellular alphasynuclein. Int J Biochem Cell Biol 40(9):1835-1849

42. Lee HJ, Suk JE, Bae EJ, Lee SJ (2008) Clearance and deposition of extracellular alpha-synuclein aggregates in microglia. Biochem Biophys Res Commun 372(3):423-428 
43. Luk KC, Kehm V, Carroll J, Zhang B, O’Brien P, Trojanowski JQ, Lee VM (2012) Pathological alpha-synuclein transmission initiates Parkinson-like neurodegeneration in nontransgenic mice. Science 338(6109):949-953

44. Luk KC, Kehm VM, Zhang B, O'Brien P, Trojanowski JQ, Lee VM (2012) Intracerebral inoculation of pathological alpha-synuclein initiates a rapidly progressive neurodegenerative alphasynucleinopathy in mice. J Exp Med

45. Luk KC, Song C, O'Brien P, Stieber A, Branch JR, Brunden KR, Trojanowski JQ, Lee VM (2009) Exogenous alpha-synuclein fibrils seed the formation of Lewy body-like intracellular inclusions in cultured cells. Proc Natl Acad Sci USA 106(47):20051-20056

46. Masuda-Suzukake M, Nonaka T, Hosokawa M, Oikawa T, Arai T, Akiyama H, Mann DM, Hasegawa M (2013) Prion-like spreading of pathological alpha-synuclein in brain. Brain $136(\mathrm{Pt}$ 4):1128-1138

47. Mohedano-Moriano A, de la Rosa-Prieto C, Saiz-Sanchez D, Ubeda-Banon I, Pro-Sistiaga P, de Moya-Pinilla M, MartinezMarcos A (2012) Centrifugal telencephalic afferent connections to the main and accessory olfactory bulbs. Front Neuroanat 6:19

48. Mook Jo S, Kuk Kim Y, Wang Z, Danscher G (2002) Retrograde tracing of zinc-enriched (ZEN) neuronal somata projecting to the olfactory bulb. Brain Res 956(2):230-235

49. Nagayama S, Enerva A, Fletcher ML, Masurkar AV, Igarashi KM, Mori K, Chen WR (2010) Differential axonal projection of mitral and tufted cells in the mouse main olfactory system. Front Neural Circuits 4

50. Nonaka T, Watanabe ST, Iwatsubo T, Hasegawa M (2010) Seeded aggregation and toxicity of $\alpha$-synuclein and tau: cellular models of neurodegenerative diseases. J Biol Chem 285(45):34885-34898

51. Oztas E (2003) Neuronal tracing. Neuroanatomy 2:2-5

52. Price JL (1987) The central olfactory and accessory olfactory structures. In: Finger TE, Silver WL (eds) The neurobiology of taste and smell. Wiley, New York, pp 179-203

53. Raisman G (1972) An experimental study of the projection of the amygdala to the accessory olfactory bulb and its relationship to the concept of a dual olfactory system. Exp Brain Res 14(4):395-408
54. Reyher CK, Schwerdtfeger WK, Baumgarten HG (1988) Interbulbar axonal collateralization and morphology of anterior olfactory nucleus neurons in the rat. Brain Res Bull 20(5):549-566

55. Roy S, Zhang B, Lee VM, Trojanowski JQ (2005) Axonal transport defects: a common theme in neurodegenerative diseases. Acta Neuropathol 109(1):5-13

56. Scott DA, Das U, Tang Y, Roy S (2011) Mechanistic logic underlying the axonal transport of cytosolic proteins. Neuron 70(3):441-454

57. Serpell LC, Berriman J, Jakes R, Goedert M, Crowther RA (2000) Fiber diffraction of synthetic alpha-synuclein filaments shows amyloid-like cross-beta conformation. Proc Natl Acad Sci USA 97(9):4897-4902

58. Spillantini MG, Schmidt ML, Lee VM, Trojanowski JQ, Jakes R, Goedert M (1997) Alpha-synuclein in Lewy bodies. Nature 388(6645):839-840

59. Tang Y, Das U, Scott DA, Roy S (2012) The slow axonal transport of alpha-synuclein-mechanistic commonalities amongst diverse cytosolic cargoes. Cytoskeleton (Hoboken) 69(7):506-513

60. Ulusoy A, Rusconi R, Perez-Revuelta BI, Musgrove RE, Helwig M, Winzen-Reichert B, Monte DA (2013) Caudo-rostral brain spreading of alpha-synuclein through vagal connections. EMBO Mol Med 5(7):1119-1127

61. Volpicelli-Daley LA, Luk KC, Patel TP, Tanik SA, Riddle DM, Stieber A, Meaney DF, Trojanowski JQ, Lee VM (2011) Exogenous alpha-synuclein fibrils induce Lewy body pathology leading to synaptic dysfunction and neuron death. Neuron 72(1):57-71

62. Waxman EA, Giasson BI (2010) A novel, high-efficiency cellular model of fibrillar alpha-synuclein inclusions and the examination of mutations that inhibit amyloid formation. J Neurochem 113(2):374-388

63. Winner B, Jappelli R, Maji SK, Desplats PA, Boyer L, Aigner S, Hetzer C, Loher T, Vilar M, Campioni S, Tzitzilonis C, Soragni A, Jessberger S, Mira H, Consiglio A, Pham E, Masliah E, Gage FH, Riek R (2011) In vivo demonstration that alpha-synuclein oligomers are toxic. Proc Natl Acad Sci USA 108(10):4194-4199

64. Zhang W, Wang T, Pei Z, Miller DS, Wu X, Block ML, Wilson B, Zhou Y, Hong JS, Zhang J (2005) Aggregated alpha-synuclein activates microglia: a process leading to disease progression in Parkinson's disease. Faseb J 19(6):533-542 